\title{
COMPARATIVE STUDY OF THE FLUVIAL PLAIN BASED ON THE GEOMORPHOLOGICAL LAND CLASSIFICATION
}

\section{Masahiko OYA*}

\section{Purpose and method of the study}

Purpose Utilizing many geomorphological land classification maps of fluvial plains, the author (Oya, $1971 \mathrm{c}$ ) has classified the fluvial plain based on morphological characteristics. In this study, the following factors in the formation of the fluvial plain have been selected by the author; a) characteristics of materials, i. e. whether they are coarse or fine, b) the stage of development in the cycle of deposition, c) rivers as the agent, and d) the place of deposition (Table 1).

Traditional studies of the fluvial plain have made clear the features and agents of each topographical element. But there are a few papers containing comparative studies of the fluvial plain based on geomorphological land classification. Therefore, the author wants to discuss the regional differences of the fluvial plain based on the relationships between the combination of the geomorphological elements and fluvial action of the river.

Before the present study, the author (Oya, $1973 \mathrm{~b}$ ) found that the combination of the geomorphological elements as shown in Table 2, is seen basically in the fluvial plain. But there are distinct regional differences in the combination of the geomorphological elements in the various fluvial plains.

The author wants to discuss specifically what kind of combination of geomorphological

Table 1 Classification of the fluvial plain

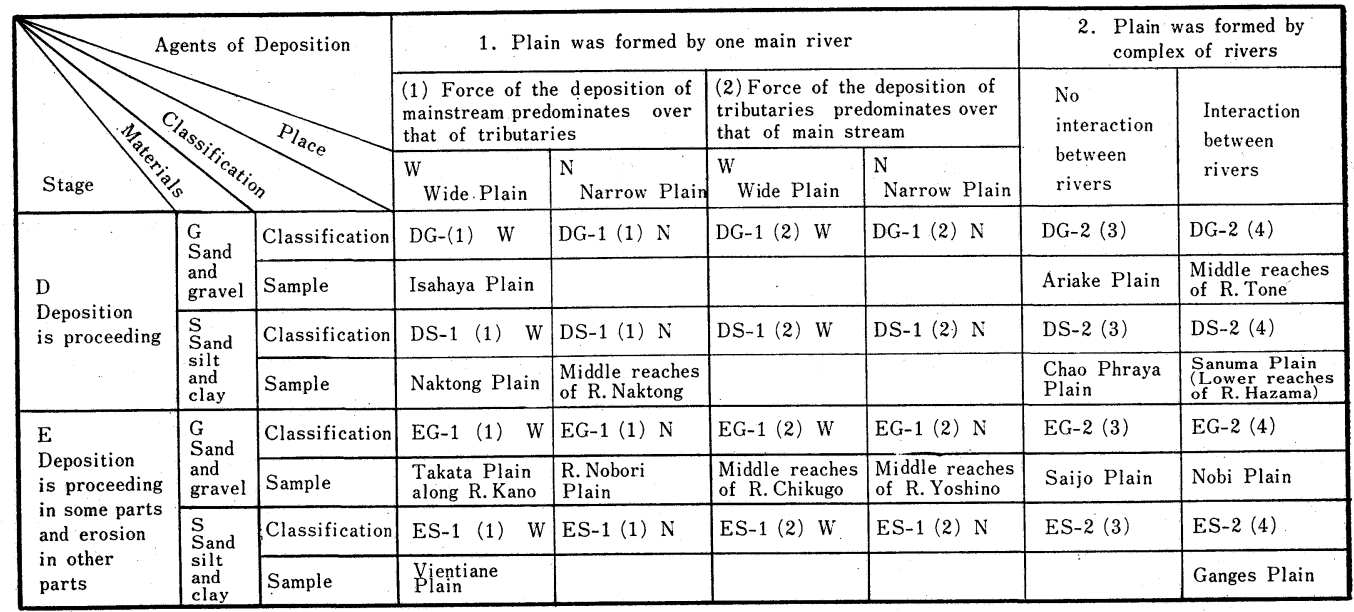

* Waseda University 
Table 2 Basic-form of the combination of the geomorphologic elements in the fluvial plain

\begin{tabular}{|c|c|c|c|c|c|}
\hline \multirow{3}{*}{ 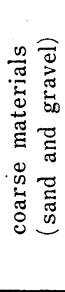 } & & Subaerial deposition & Tidal deposition & 'Subaquatic deposition & Sample \\
\hline & Lake & $\begin{array}{l}\text { fan, natural levee } \\
\text { back marsh } \\
\text { lowland between natural levee }\end{array}$ & & delta with foreset bed & Yasugawa Plain \\
\hline & Sea & $\begin{array}{l}\text { fan, natural levee } \\
\text { back marsh } \\
\text { lowland between natural levee }\end{array}$ & $\begin{array}{l}\text { delta } \\
\text { natural levee formed } \\
\text { by high tide }\end{array}$ & delta with foreset bed & Nobi Plain \\
\hline \multirow{2}{*}{ 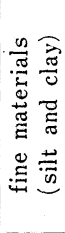 } & Lake & $\begin{array}{l}\text { natural levee } \\
\text { back marsh } \\
\text { lowland between natural levee }\end{array}$ & & $\begin{array}{l}\text { delta without foreset } \\
\text { bed }\end{array}$ & Kawachi Plain \\
\hline & Sea & $\begin{array}{l}\text { natural levee } \\
\text { back marsh } \\
\text { lowland between natural levee }\end{array}$ & $\begin{array}{l}\text { delta } \\
\text { natural levee formed } \\
\quad \text { by high tide }\end{array}$ & $\begin{array}{l}\text { delta without foreset } \\
\text { bed }\end{array}$ & Chao Phraya Plain \\
\hline
\end{tabular}

(Oya, 1973 b)

elements of the fluvial plain has been formed by the relationship between the geomorphology and the geology in the upper reaches, laying stress on whether the intermontane basins are located in the upper reaches or not.

As a result of the study, the author believes that the influence and characteristics of the crustal movement and the eustatic movement on the formation of the fluvial plain will become clear in the near future.

Method Firstly, the author has systematically studied 13 main fluvial plains in Japan that are relatively small in size but whose geomorphological features are well known from many geomorphological studies, together with three large fluvial plains in Europe and North America. Secondly, using the same method, the author studied 8 large fluvial plains in East and South East Asia which have received little geomorphological study (Fig. 1). Based on the specific studies, the author has discussed the regional differences of the fluvial plain inductively.

As the foundation of the studies, the author has used many geomorphological land classification maps which have been prepared by him during the last 20 years, utilizing aerial photographs, photographs from the Earth Resources Technology Satellite, and field survey data. These methods have revealed some facts about the geomorphological elements and their combination in the plain. The author used the results as the basic materials of the comparative studies of the plain.

In order to investigate the influence of the deposition and erosion in the intermontane basins and gorges along the river course on the plains, the author has also analysed the river bed sediments in several important rivers and made clear the regional differences of the fluvial plains which have been formed by the regional differences of the fluvial action.

Throughout the study, the author has gained confidence that the method of geomorphological land classification is very useful for observing clearly the geomorphological elements and their combinations. The author believes that if we apply the method which has been devised in Japan to East and South East Asia where there are few geomorphological studies, 
2. SHŌNAI PLAIN

3. YAMAGATA INTERMONTANE DEPRESSION

4. TONE RIVER PLAIN

5. KANO RIVER PLAIN

6. NOBI PLAIN

7. KUZURYU RIVER PLAIN

8. ŌSAKA PLAIN

9. YOSHINO RIVER PLAIN

10. SAIJO PLAIN

11. CHIKUGO PLAIN

12. ISAHAYA PLAIN

13. KIMOTSUKI PLAIN

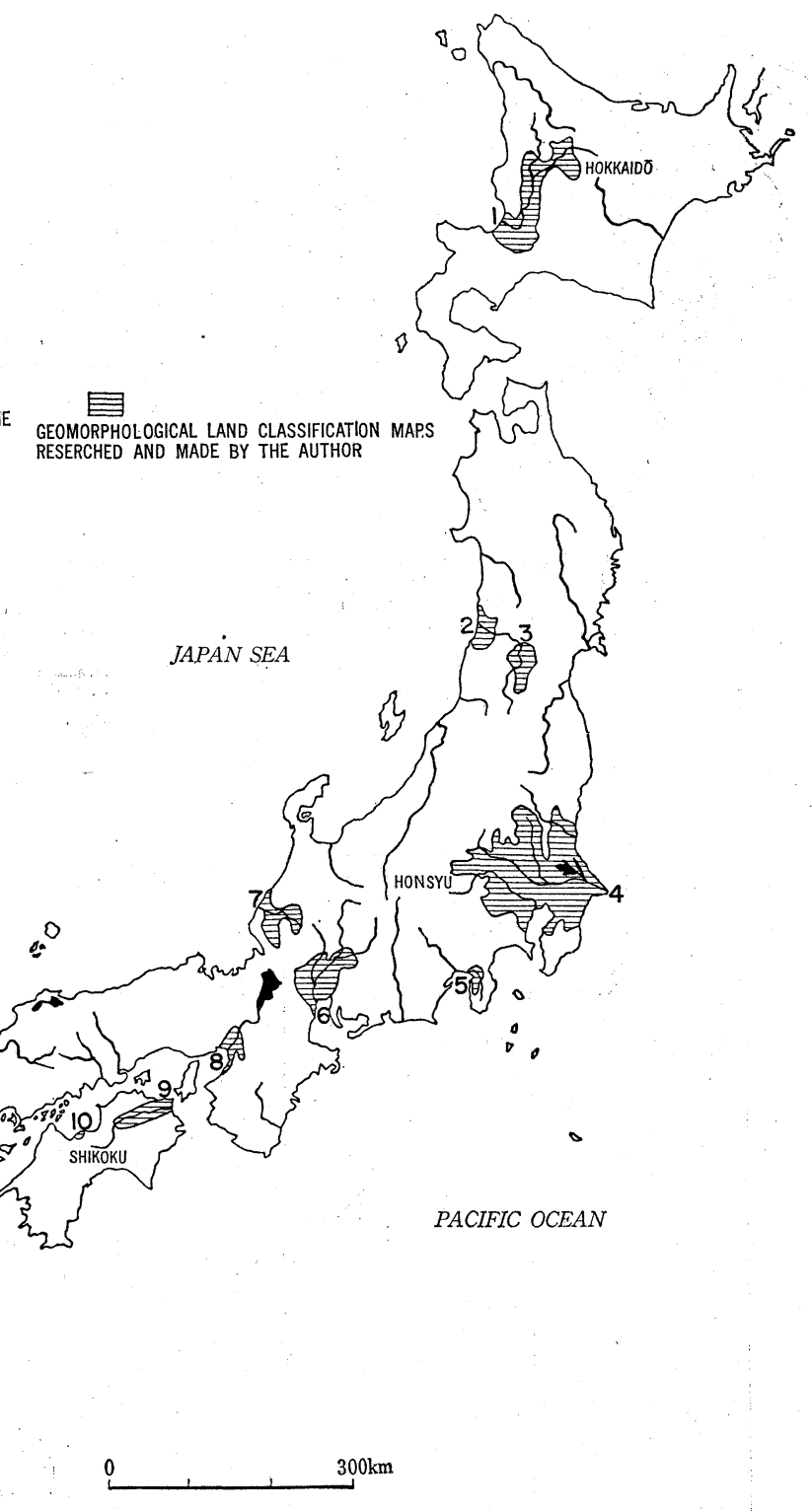

Fig. 1-1 Research area (Japan)

we can gain the geomorphological knowledge of the area easily and rapidly.

The author defined the fluvial plain as follows : a fluvial plian has been formed by the gravel, sand, silt and clay which have been transported by rivers and deposited along the sea shore, lake side or intermontane basins. The age of formation is Holocene.

\section{Comparison of the fluvial plain}

1. Classification of the fluvial plain based on the orogenic zone or epeirogenic zone, and. 


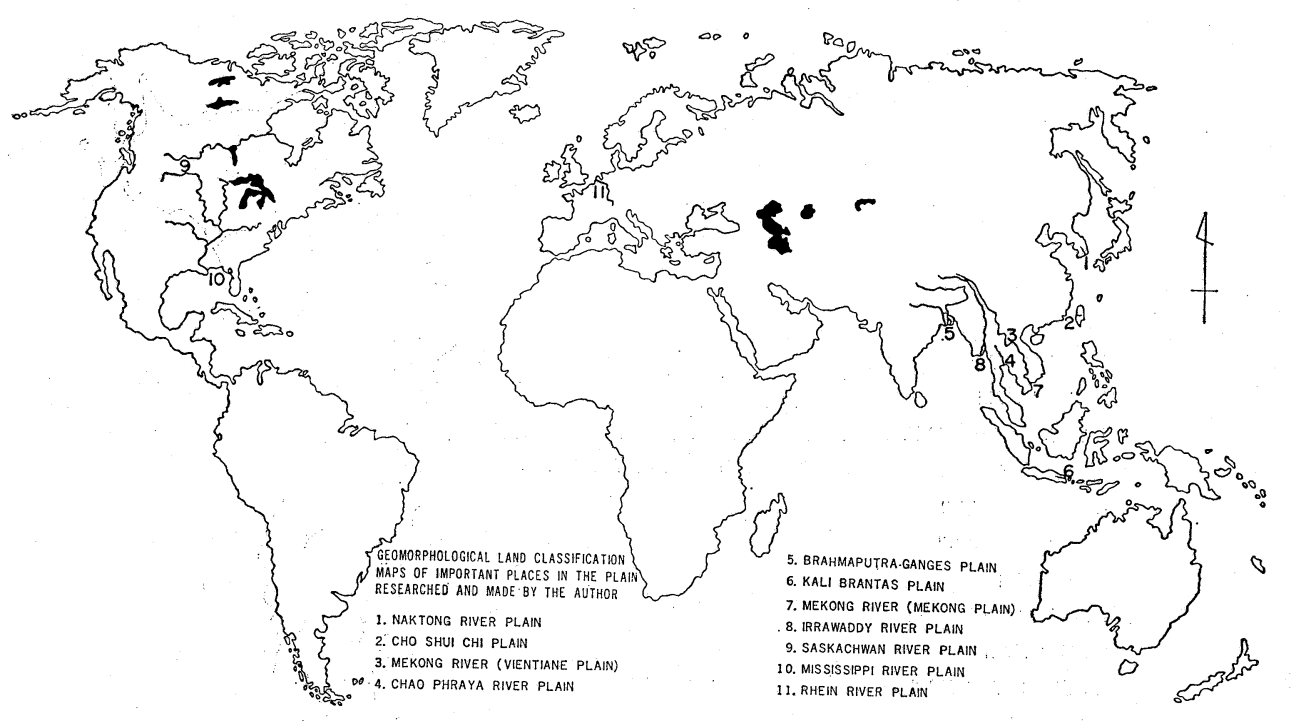

Fig. 1-2 Reserach area (World)

Table 3 Combination of the geomorphologic elements in the fluvial plain which has no intermontane basin in the upper reaches in the orogenic zone "On" group

\begin{tabular}{|c|c|c|}
\hline RIVER NAME & PLAIN NAME & COMBINATION OF THE GEOMORPHOLOGIC ELEMENTS \\
\hline R. IWAKI & TSUGARU PLAIN & $\begin{array}{l}\text { R. IWAKI } \\
\mathrm{f} \\
\text { R. Daiwasawa } \\
\text { Sandy } \mathrm{f} \\
\text { R. Karachiku } \\
\text { Dissected } \mathrm{f}-\text { FISSECTED } \\
\text { R. Aseishi }\end{array}$ \\
\hline R. TSURUMI & TSURUMI PLAIN & N.L (B)...D \\
\hline R. KANO & TAKATA PLAIN & $F(V . P) \ldots N . L(B)$ \\
\hline R. KISO & NOBI PLAIN & $\begin{array}{l}\text { DISSECTED BIG F-F-BIG N.L (B) } \\
\text { R. KISO } \\
\text { R. NAGARA } \\
\text { R. IBI }\end{array}$ \\
\hline CHO SHUI CHI & TAIWAN PLAIN & BIG STEEP F...SHORT N. L...SHORT STEEP D \\
\hline $\begin{array}{l}\text { R. BRAHMA PUTRA- } \\
\text { JAMUNA }\end{array}$ & $\begin{array}{l}\text { BRAHMAPUTRA-JAMUNA } \\
\text { PLAIN }\end{array}$ & $\begin{array}{l}\text { n.1 (b) } \\
\text { LONG, SLENDER SMALL } \\
\text { SANDY F-N.L (B) }>\text { D } \\
\text { R. BRAHMAPUTRA JAMUNA } \\
\text { R.1 (b) GANGES } \\
\text { R. Tista }\end{array}$ \\
\hline
\end{tabular}

F : Fan V. P : Valley Plain N. L (B) : Natural Levee and Back Marsh D: Delta S : Sand Dune S. S: Sand Spits Capital letter shows main stream, Small letter shows tributary. The foot note is common to Tables 3,4 and 5 .

whether the rivers have intermontane basins in the upper reaches or not.

Based on the location, the author has classified the fluvial plain into two groups. First, the fluvial plain located in the orogenic zone " $O$ " group and the epeirogenic zone "E" group. Further, the "O" group is classified as follows : the "Od" group which has inter- 
Table 4 Combination of the geomorpholcgic elements in the fluvial plain which has intermontane basins and gorges with knick points in the orogenic zone "Od" group

\begin{tabular}{|c|c|c|}
\hline RIVER NAME & PLAIN NAME & COMBINATION OF THE GEOMORPHOLOGIC ELEMENTS \\
\hline R. ISHIKARI & ISHIKARI PLAIN & SMALL F-BIG N.L (B) ...D \\
\hline \multirow[t]{2}{*}{ R. MOGAMI } & $\begin{array}{l}\text { YAMAGATA } \\
\text { INTERMONTANE } \\
\text { BASIN }\end{array}$ & $\begin{array}{l}f \\
\downarrow \\
\substack{f \\
\uparrow} \\
f\end{array}$ \\
\hline & SHONAI PLAIN & $\begin{array}{l}\text { f-n. l-d } \\
\text { R.Aka } \\
\text { SMALL F-DISSECTED D }=S \\
\text { f-n. l-d- } \\
\text { R. Gakko, R. Nikko }\end{array}$ \\
\hline \multirow[t]{2}{*}{ R. TONE } & $\begin{array}{l}\text { R. TONE MIDDLE } \\
\text { REACHES PLAIN }\end{array}$ & 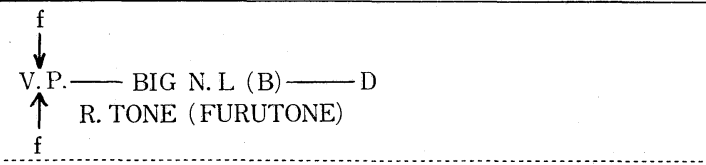 \\
\hline & $\begin{array}{l}\text { R. TONE LOWER } \\
\text { REACHES PLAIN }\end{array}$ & $\begin{array}{ll}\text { n.l }(\mathrm{b}) & \\
\text { R. Kinu } & \text { D. TONE } \\
\end{array}$ \\
\hline R. KANO & NUMAZU PLAIN & D - R. KANO \\
\hline R. KUZURYU & FUKUI PLAIN & $\begin{array}{l}\text { SMALL F-DISSECTED F-SMALL N.L-BIG D } \\
\text { R. KUZURYU }\end{array}$ \\
\hline $\begin{array}{l}\text { R. YAMATO } \\
\text { R. YODO }\end{array}$ & OSAKA PLAIN & $\begin{array}{l}\text { R. YODO } \\
\text { BIG N.L (B) } \\
\text { R. YAMATO }\end{array}$ \\
\hline R. CHIKUGO & CHIKUGO PLAIN & 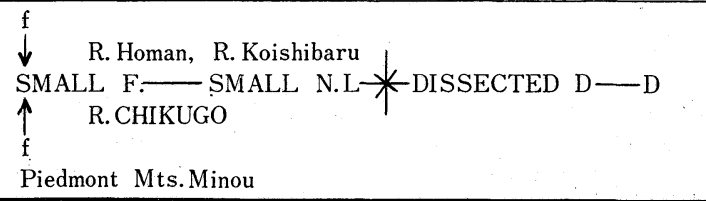 \\
\hline
\end{tabular}

Table 5 Combination of the geomorphologic elements in the fluvial plain in the epeirogenic zone "E" group

\begin{tabular}{|c|c|c|}
\hline RIVER NAME & PLAIN NAME & $\begin{array}{l}\text { COMBINATION OF THE GEOMORPHOLO- } \\
\text { GIC ELEMENTS }\end{array}$ \\
\hline R. NAKTONG & NAKTONG PLAIN & BIG N. L (B) ......D \\
\hline \multirow{2}{*}{ R. MEKONG } & VIENTIANE PLAIN & N. L (B) \\
\hline & MEKONG PLAIN & N. L (B).....D \\
\hline R. CHAO PHRAYA & CHAOPHRAYA PLAIN & BIG N.L (B).....D \\
\hline
\end{tabular}

montane basins and gorges with knick points, and the "On" group which dose not have intermontane basins in the upper reaches.

Table 3 shows the combination of the geomorphological elements in the fluvial plain 
Table 6 Comparison on the relief energies between

Kiso River Basin and Chikugo River Basin

\begin{tabular}{|c|rr|rr|}
\hline Relief Energy & \multicolumn{2}{|c|}{ Kiso River } & \multicolumn{2}{|c|}{ Chikugo River } \\
\hline $\mathrm{m}$ & $\mathrm{km}^{2}$ & $\%$ & $\mathrm{~km}^{2}$ & $\%$ \\
0 & 15.92 & $(0.3)$ & 161.20 & $(11.2)$ \\
100 & 164.32 & $(3.3)$ & 190.64 & $(13.2)$ \\
200 & 253.12 & $(5.2)$ & 369.44 & $(25.6)$ \\
300 & 532.64 & $(10.8)$ & 339.28 & $(23.5)$ \\
400 & 790.88 & $(16.2)$ & 202.08 & $(14.0)$ \\
500 & 896.96 & $(18.3)$ & 154.32 & $(10.7)$ \\
600 & 742.96 & $(15.1)$ & 10.00 & $(0.7)$ \\
700 & 491.92 & $(10.0)$ & 16.00 & $(1.1)$ \\
800 & 307.04 & $(6.3)$ & & \\
900 & 237.60 & $(4.8)$ & & \\
1000 & 168.40 & $(3.4)$ & & \\
1100 & 77.20 & $(1.6)$ & & \\
1200 & 143.68 & $(2.9)$ & & \\
1300 & 87.84 & $(1.8)$ & & \\
\hline
\end{tabular}

(Oya, 1973 a)

which has no intermontane basins in the upper reaches in the orogenic zone (the "On" group). Table 4 shows the combination of the geomorphological elements in the fluvial plain which has intermontane basins and gorges with knick points (the "Od" group). Table 5 shows the combination of geomorphological elements in the fluvial plain in the epeirogenic zone (the "E" group). These tables have been made based on the geomorphological land classification maps which have been prepared by the author. They indicate that the fluvial plains of each group, i. e. "On", "Od" and "E", have individual features and distinct regional differences among the groups.

The features in each group are summarized as follows :

"On" group : Almost all the plains are constructed by the fan, natural levee and back marsh, and the delta. The fan is generally big.

"Od" group : The fan is non-existent or small in this group. There are mostly natural levee and back marsh and delta in the plain; but in some plains, there are few natural levee and back marsh.

"E" group : There are few alluvial fans in this group. All plains are constructed by the natural levee, back marsh and delta.

2. Features and agents of the fluvial plain in each of the classified groups.

"On" group

(1) Features of the fan

Features common to them all Except for the Tsurumi Plain, all plains have large alluvial fans (Table 7-1). The reason for the development of such large alluvial fans is that a lot of sand and gravel has been furnished, depending on whether the stage in the cycle of erosion of the drainage area is in the early mature or fully mature stage and on whether erosion is still continuing. 
Table 7 Radius and area of the fan

(1) Fans which have no intermontane basins in the upper reaches "On" group

\begin{tabular}{|l|c|c|}
\hline \multicolumn{1}{|c|}{ Name of river } & Radius $(\mathrm{km})$ & Area $\left(\mathrm{km}^{2}\right)$ \\
\hline R. Iwaki & 9 & \\
(along R. Aseishi) & $(12)$ & \\
R. Kiso & 12 & 101 \\
R. Cho Shui Chi & 13 & \\
\hline
\end{tabular}

(2) Fans which have intermontane basins and gorges with knick points "Od" group

\begin{tabular}{|l|c|r|}
\hline \multicolumn{1}{|c|}{ Name of river } & Radius (km) & Area $\left(\mathrm{km}^{2}\right)$ \\
\hline R. Ishikari (lower reaches of the Kamuikotan Gorge) & 2 & \\
R. Mogami (lower reaches of the Mogami Gorge) & 2 & \\
R. Kuzuryu (lower reaches of the Katsuyama Narrow) & 5 & 23.5 \\
R. Chikugo (lower reaches of the Yoake Gorge) & 3.5 & 9.5 \\
\hline
\end{tabular}

Especially, in the case of the Kiso River and Cho Shui Chi, the large fans have developed as a result of the following features in the upper and middle reaches; a) the height of the mountain region is great, b) the mountains are also composed of steep slopes, c) the relief energy of the area is large showing a maximum of $1,300 \mathrm{~m}$, those over $500 \mathrm{~m}$ occupying $65.2 \%$ of the whole drainage area of the Kiso River (Table 6), d) the crustal upheaval of this area are continuing; the region has been raised 5 to $11 \mathrm{~cm}$ during the past 50 to 60 years on observation of the first order bench mark located along the Kiso Valley (Oya, 1973 a), e) the geology of the area consists of rocks the mechanical disintegration of which is easy, and $f$ ) the longitudinal profile of the river is steep. The rainfall is concentrated in the summer half year.

Because of the above mentioned geomorphologic and geologic features of the basin, usually when a severe rainfall occurs, landslides follow and a lot of sand and gravel is supplied to the river bottom. Furthermore there is no intermontane basin or remarkable knick point along the river course and the river runs along a continuous gorge. Therefore, sand and gravel which is supplied by landslides dose not stop on the way but flows directly down to the plain.

The age of formation of each fan is new. Except for the fan of Kiso River which is being eroded in parts, deposition is continuing actively in the others. In the case of the alluvial fan of the Cho Shui Chi, a shifting of the river courses occurred five times during the period of 1793 to 1911 (Oya, $1964 \mathrm{a} \cdot \mathrm{b}$ ). The river bed is rising slowly but steadily, and further shifting of the river courses in the future is quite within the bounds of possibility. Due to the big flood in 1586 (Resources Council, 1956) the mainstram of the Kiso River shifted from its former course to the present course and five distributaries existed in the former river course. The writer presumed that the main stream and distributaries continued depositing before the distributaries were artificially abandoned in 1608 (Resources Council 1956).

Regional differences The alluvial fans of the Kiso River and of the Cho Shui Chi consist 


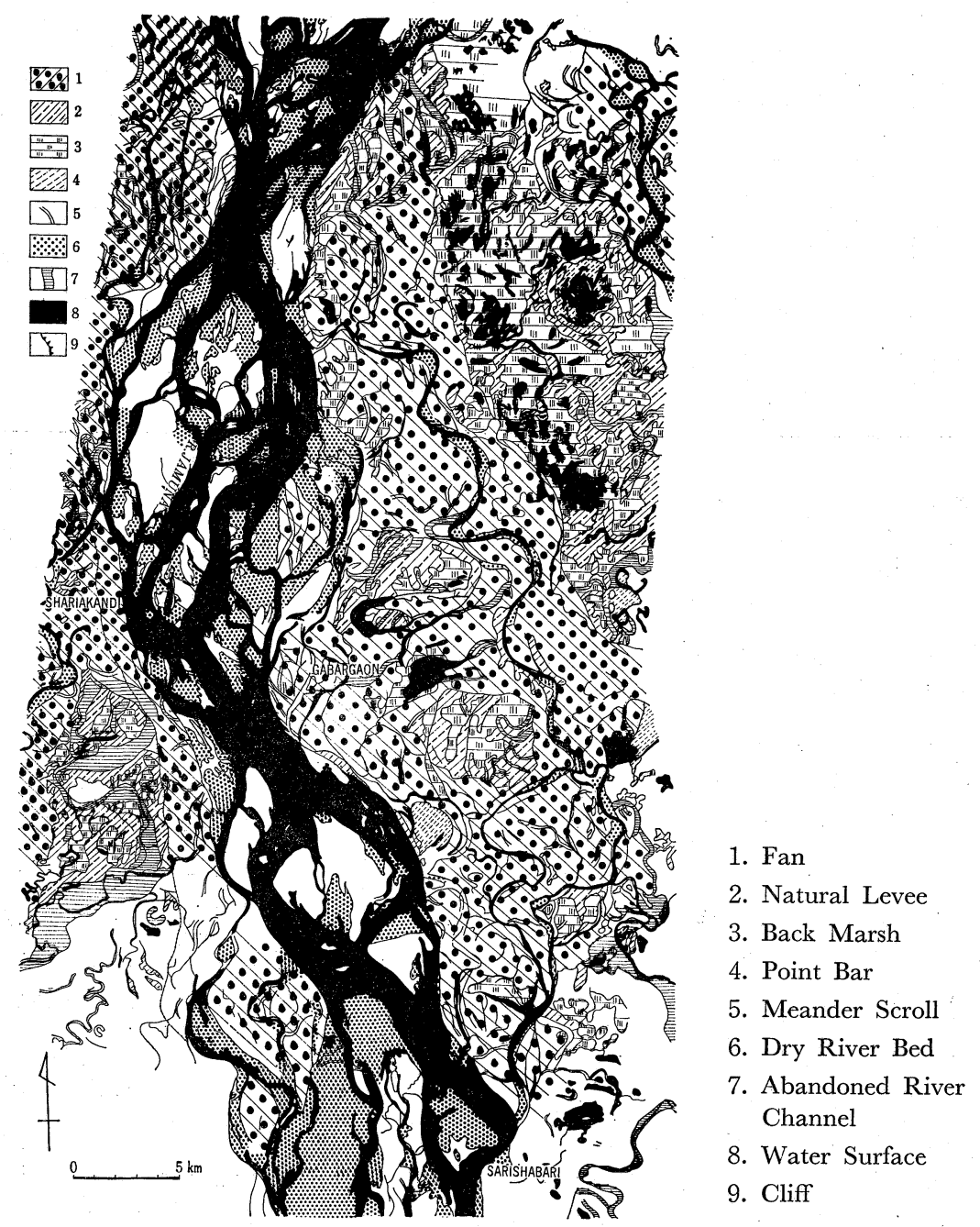

Fig. 2-1 Geomorphological land classification map of the Brahmaputra-Jamuna River Basin Bahadrbad, Gabargaon and it's Surrounding Area (Oya, 1974 a)

of coarse materials, i. e. mainly gravel ; on the other hand, the fan of the Aseishi River, a branch of the Iwaki River consists of a considerable amount of fine materials, i. e. white volcanic fine sand, ("Sirasu") which was derived from the Towada Volcano.

The slopes of the fans of the Kiso River and of the Cho Shui Chi are steep, i. e. 3.3/1,000 and 4.5/1,000. The steep slopes have been formed partly because much gravel of large size is included in the fan, partly because the volume of the sand and gravel is large, and partly because of the increasing of the slopes caused by the upward crustal movement in the mountain region.

On the other hand, the alluvial fan located in the Brahmaputra-Jamuna River is flat, i. e. 0.1/1,000 and narrow. This results from the following causes : a) upward crustal movement in the Himalaya Mountains dose not increase the slopes, because the distance from the 


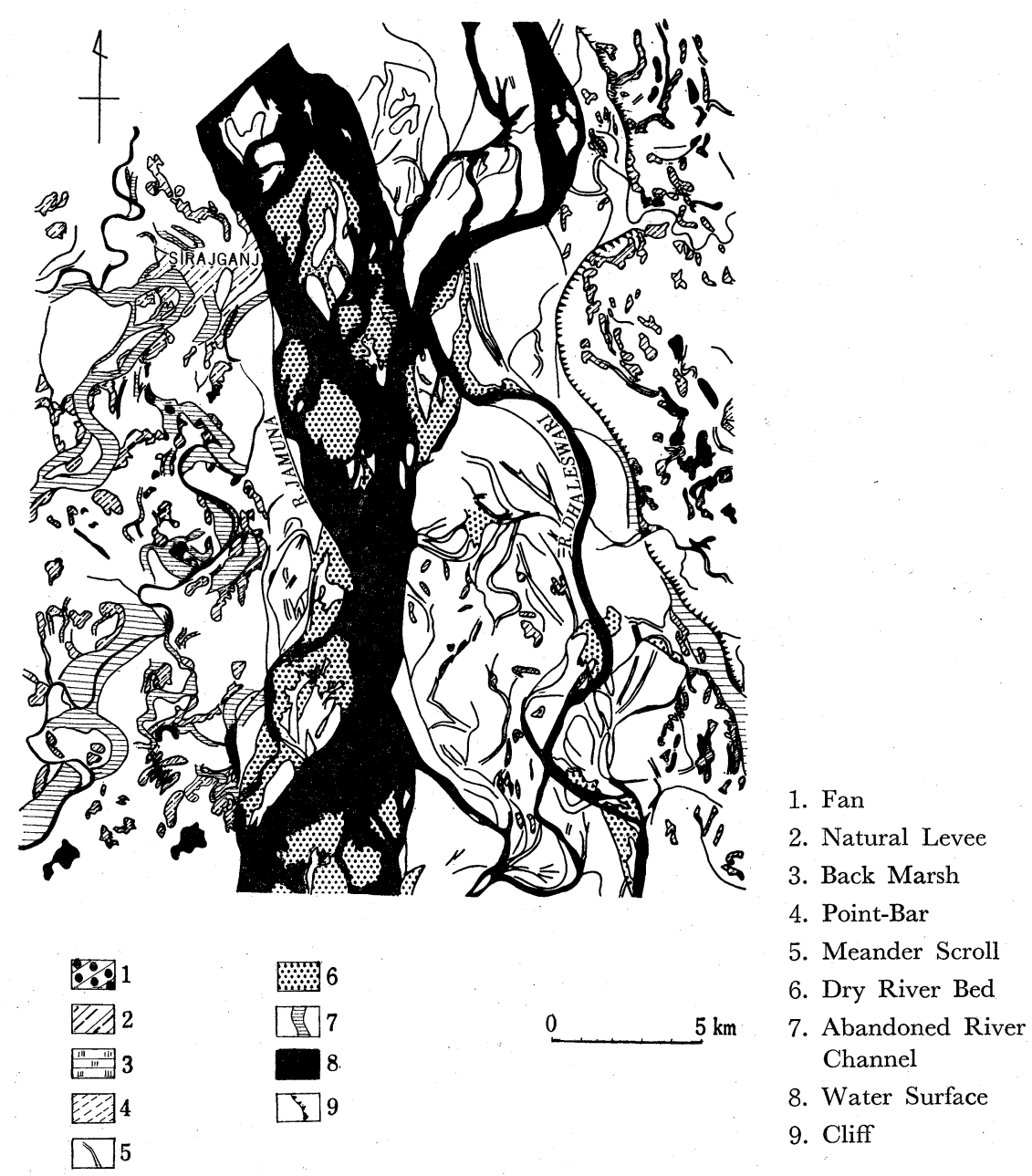

Fig. 2-2 Geomorphological land classification map of the Brahmaputra-Jamuna River Basin Sirajganj and its surrounding area (Oya, 1974 a)

mountains to the area is too great, b) the fan mainly consists of sand, c) the amount of deposition of the fan is insufficient because only 145 to 165 years have passed from the beginning of the deposition of the fan when the Brahmaputra River shifted from the Old Brahmaputra to its present course between 1720 and 1830 (Morgan \& McIntire, 1959), d) the old fluvial plain which was the base of the fan is a natural levee and back marsh region which were formed by the Tista River and they were very flat. At present the alluvial fan is formed by the Brahmaputra covering natural levee, back marsh, and former river courses. Thus specialized features of the combination of topographic elements are formed by the above mentioned shifting of the rivers (Oya, 1974 a) (Fig. 2-1).

As has been mentioned above, there are distinct regional differences between the features (materials, slope etc.) of the Brahmaputra-Jamuna River and Kiso or Cho Shui River.

The Kiso River formed the typical alluvial fans (Fig. 3). But in the case of the Iwaki 


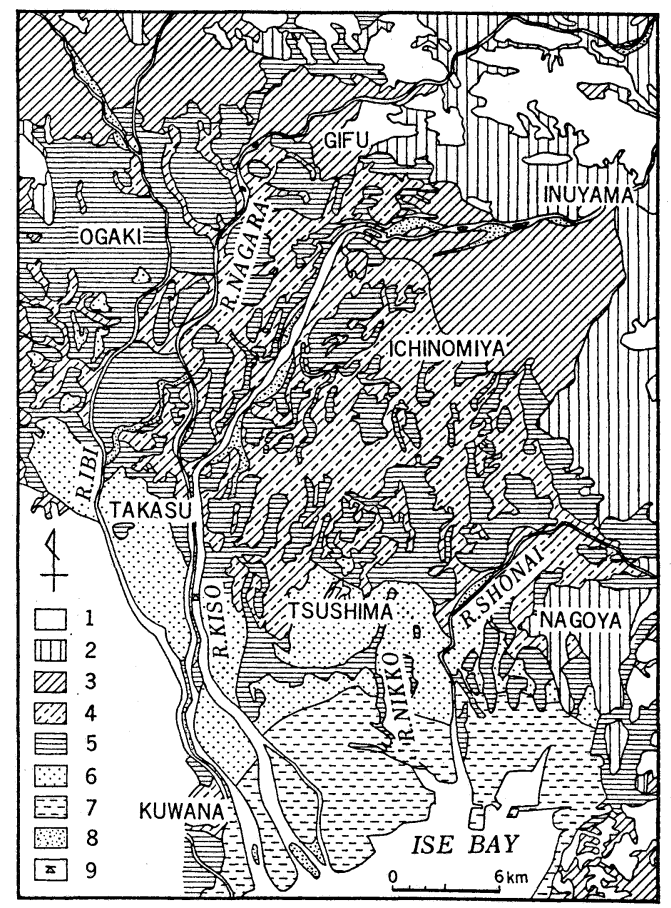

1. Mountain

2. Terrace

3. Fan

4. Natural Levee

5. Back Marsh

6. Delta

7. Reclaimed Land

8. Dry River Bed

9. Tidal Limit

Fig. 3 Geomorphological land classification map of the Nobi Plain

River, except for the fan located in the right bank of the Aseishi River, the shape of the fan is irregular because of the interruption of the mainstream by branch streams, i. e. Hirakawa River, Aseishi River and so forth (Fig. 4).

The reasons for the lack of a fan in the Tsurumi River could be considered to be, a) there is no gravel produced in the upper reaches due to the lack of mountains, b) the gradient of the river is gentle, and c) the width of the plain is narrow, only $0.5-0.6 \mathrm{~km}$ in the upper reaches.

(2) Features of the natural levee

Features common to them all Natural levee have developed on all plains of the "On" group. Every natural levee has developed well and continuously in all plains except for the Brahmaputra-Jamuna River. The reason why the natural levees have been developed is that, sand, silt and clay which compose the natural levees have been produced in quantities in the upper reaches. Depending on the development of the natural levee, the nearer to the river the land is, the higher it becomes (Fig. 5). Thus when a flood occurs, the flood water overflows from the natural levee to the back marsh or delta (Oya, $1973 \mathrm{a}$ ). Thus, the building of the natural levee continues.

Regional difference The natural levees located along the Kuroda River which are the former distributaries of the Kiso River are long, about $22 \mathrm{~km}$. The natural levees in the Tsugaru Plain are long too, but the natural levees in the Cho Shui Chi Plain are short. The features imply that the subaquatic deltas which were formed during the postglacial 


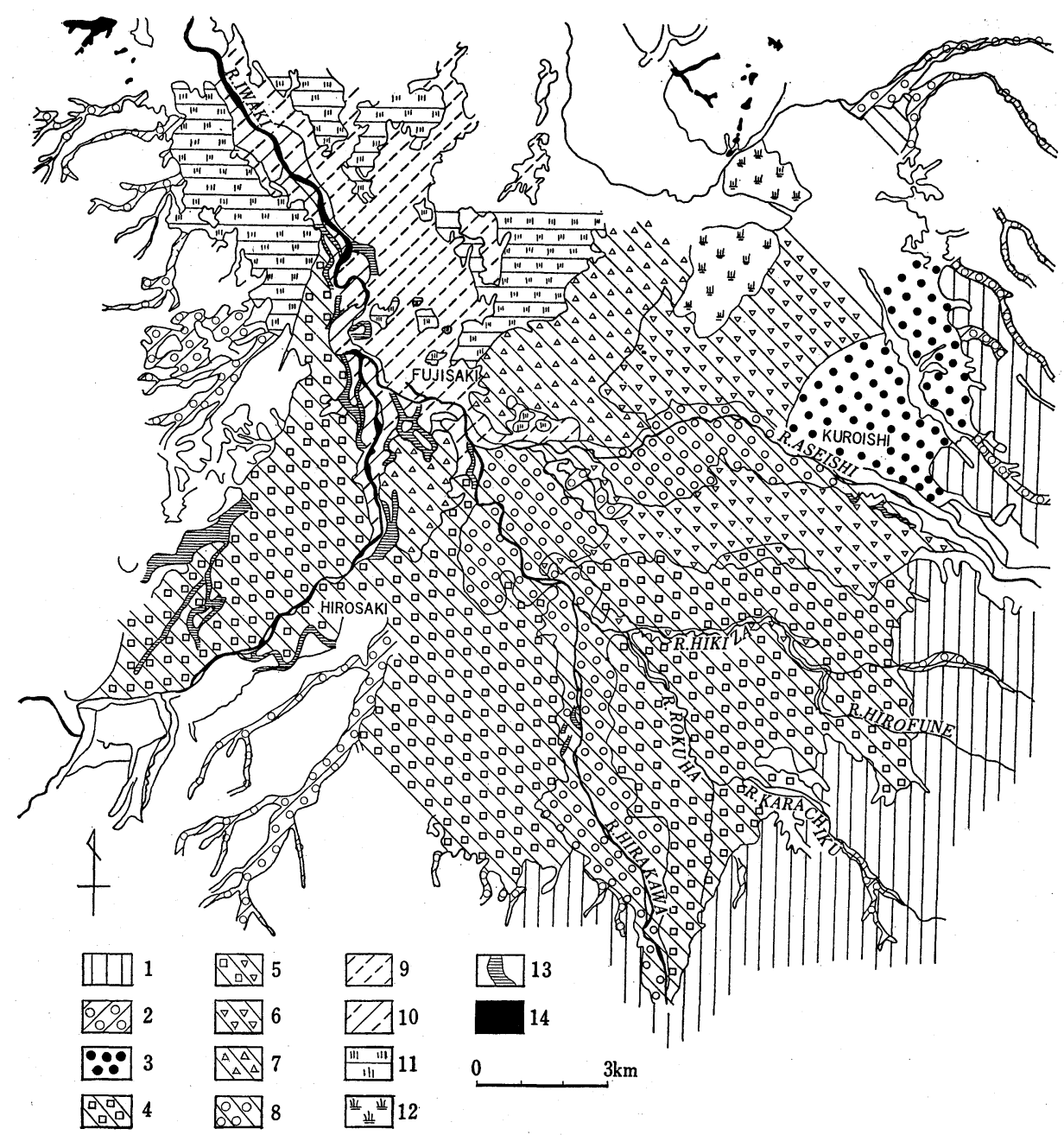

Fig. 4 Geomorphological land classification map of the southern part of the Tsugaru Plain

1. Steep Slope 2. Valley Plain 3. Fan I 4. Fan II 5. Fan-between II and III 6. Fan III 7. Fan IV 8. Fan V 9. Upper Natural Levee 10. Lower Natural Levee 11. Back Marsh 12. Marsh 13. Former River Course 14. Water Surface

rise of sea level in the early Jomon Period (around 6,000 years B. P.) are great in length in the Nobi and Tsugaru Plain but short in the Cho Shui Chi Plain.

The natural levees in the Tsugaru Plain are divided into two levels, the upper and the lower. The total width is great, about $3 \mathrm{~km}$ and the shape is very flat. According to Umitsu (1974) the upper surface of the plain was formed at the culmination of the postglacial rise of sea level in the early Jomon Period. The author presumed that the upper natural levees were formed by the repetition of moderate flooding.

In the case of the Brahmaputra-Jamuna River, the size of the natural levee is smaller than that of the Nobi Plain and it is also fragmentary. The reason why the natural levee which 

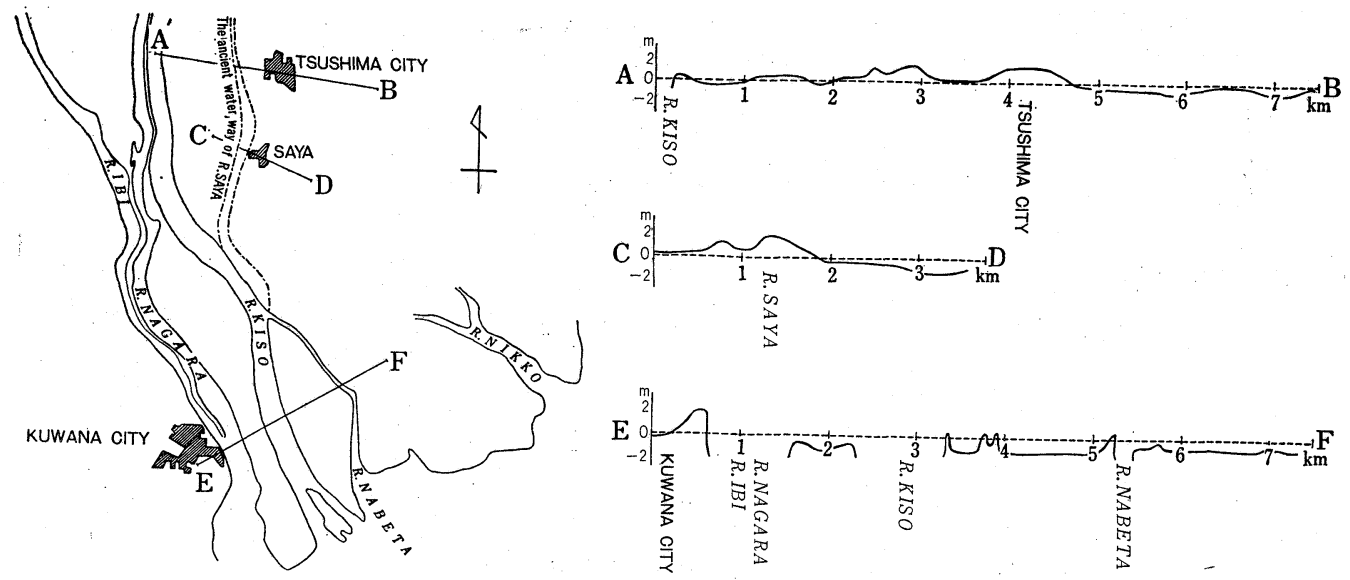

Fig. 5 Topographical cross-section of the lower reaches of the Kiso River Basin

Prepared by Oya (1973 a) utilizing topographical map which is measured by Geographical Survey Institute Ministry of Construction

was formed by the flooding in one year was destroyed by the flooding in the next year was because the variation of water level between the dry and rainy season was great and fluctuation of flooding in each year was great (Fig. 2-2).

(3) Features of the delta

Deltas occupy spaces between natural levee, back marsh area and coastline.

South of the line connecting the cities of Tsushima, Jimokuji and Nagoya in the Nobi Plain is a tidal delta. The height of the ground is low, the greater part of it is between 1 and $-2 \mathrm{~m}$ above mean sea level, and the slope is gentle, about $0.07 / 1,000$. If there were no coastal embankment the delta would be covered by sea water at high tide. The delta had been completely inundated by sea water caused by high tide formed by the Ise Wan Tyhpoon in 1959 (Nakano \& Oya, 1960 ; Oya, 1972)

The delta of the Cho Shui Chi has features of the deltaic fan, i. e. the ground elevation of the delta is from 1.7 to $1.0 \mathrm{~m}$ and has a general slope of about $1.25 \mathrm{in} 1,000$, and the soil is sandy (Oya, $1964 \mathrm{a} \cdot \mathrm{b}$ ).

In the case of the Brahmaputra-Jamuna Plain, the delta is small, only developed near the junction between the Brahmaputra-Jamuna with Ganges. A delta has been developed which was formed by the Ganges River from the junction to the coast line of the Bay of Bengal. The slope is very gentle, about $0.01 / 1,000$. This may be the gentlest in the world.

In the orogenic zone, the cycle of deposition in the fluvial plain which has no intermontane basin is at a young stage because the cycle of erosion in the mountains in the upper reaches is in the stage of youth. The combination of the geomorphological elements, fan, natural levee and back marsh, and delta is seen clearly. The regional differences on the shape and characteristics of the geomorphological elements in the plain are the result from regional differences of the natural environment-geomorphology, geology, rainfall etc.-except for the features of the depositional basin and the interruption of rivers. 


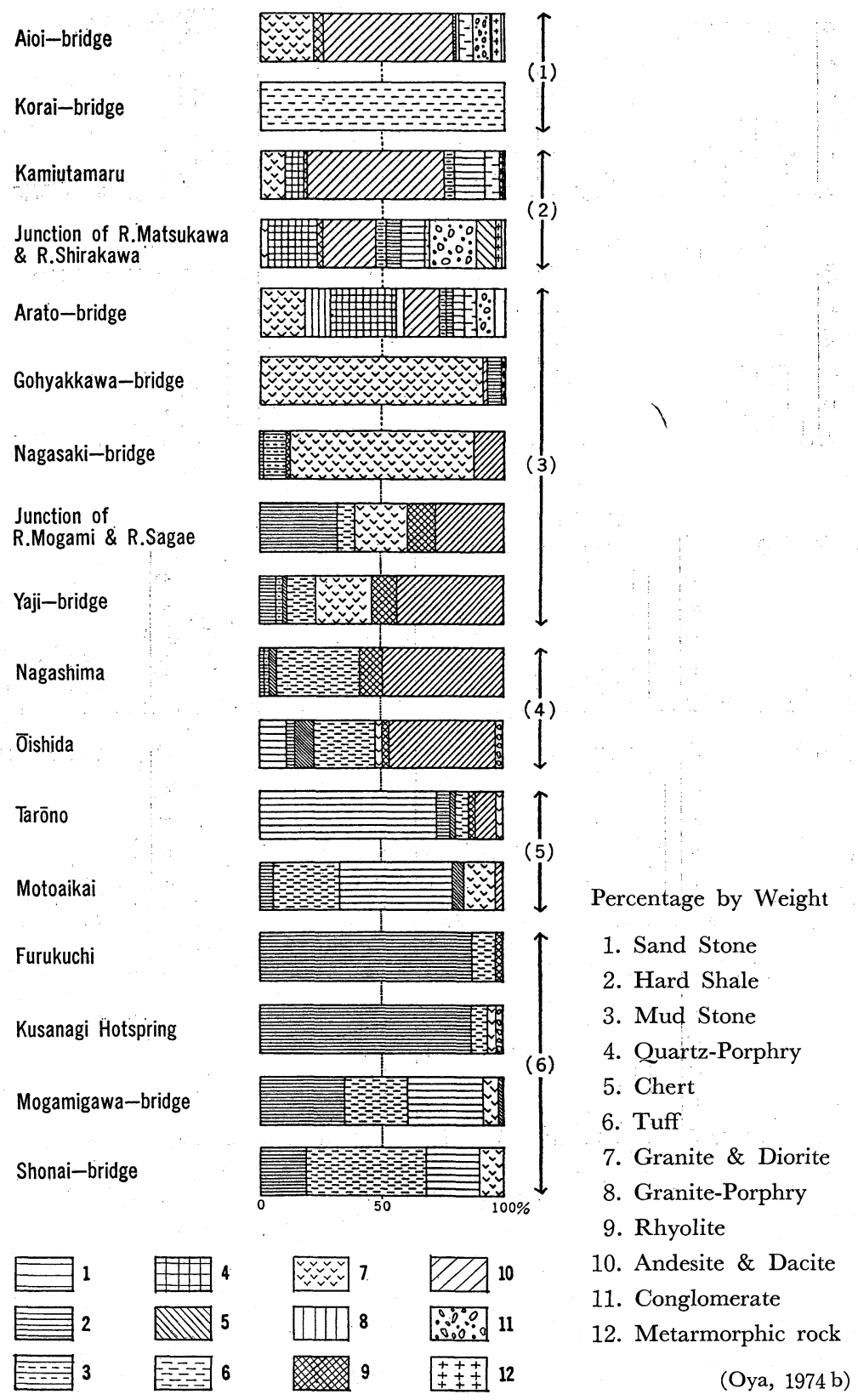

Fig. 6 Species of the river bed sediments in the Mogami River

\section{"Od" group}

(1) Features of the fan

In the plains there are small fans or none at all. Example of the former are the Ishikari River, Mogami River, the Kuzuryū River and Chikugo River (Table 7-2). Examples of the latter are the Yamagata Intermontane Basin, Plain of the lower reaches of the 

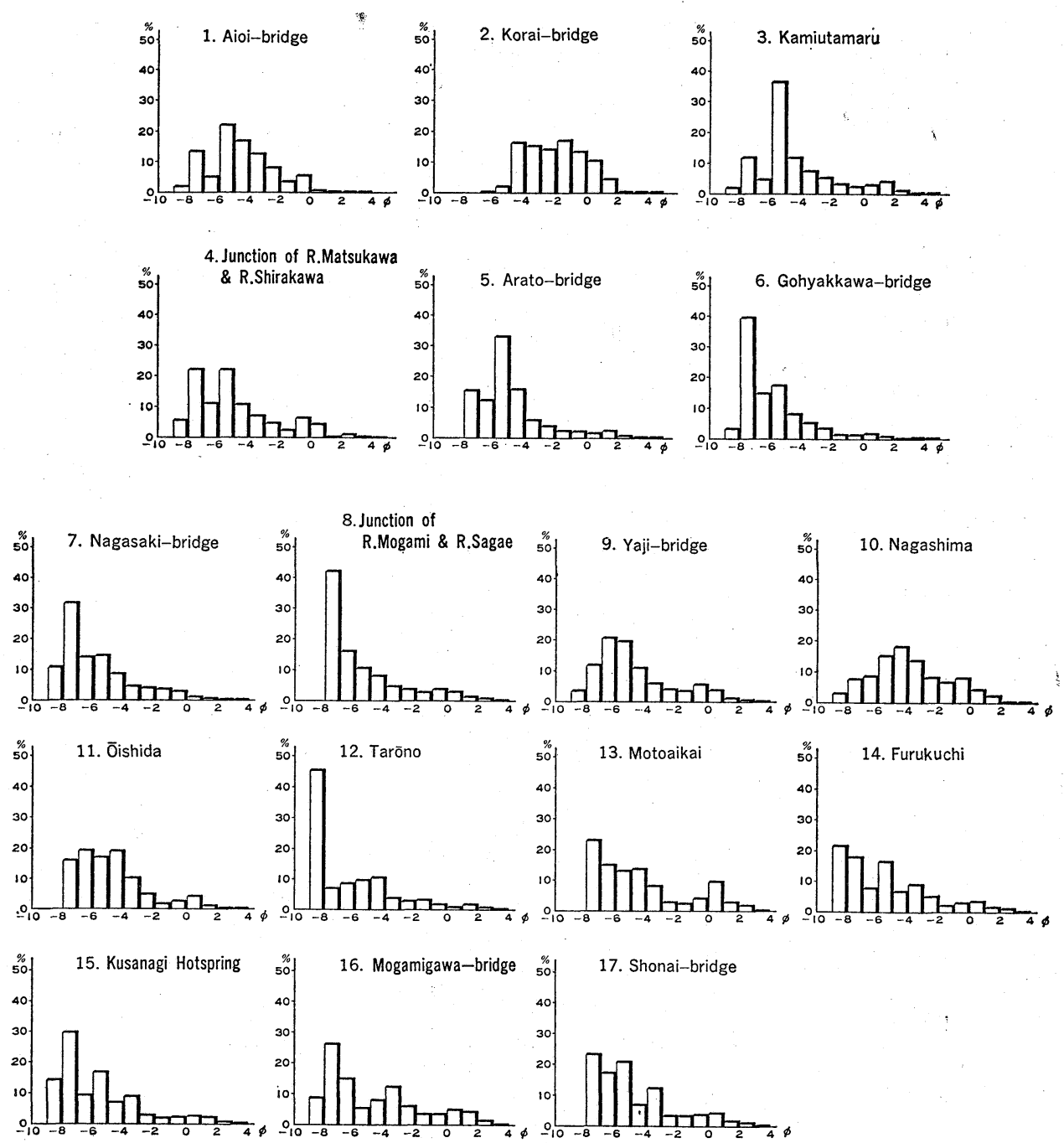

Fig. 7 Histgram of the river bed sediments in the Mogami River (Oya, 1974 b)

Tone River, and the Osaka Plain. The author has asked the question, why are the alluvial fans small or nonexistent in the plains in spite of both the drainage area and discharge being great?

The author has answered the above question by research on the lithology (on those of more than $64 \mathrm{~mm}$ in diameter), diameter and roundness of the particles of gravel in the river bed of the Mogami River, and by determing the longest diameter and their roundness in the Ishikari River and Chikugo River (Table 8)

The lithology and the grain size frequency of gravels are shown in Figs. 6 and 7. These figures show that sand and gravel are furnished in the gorges and deposited in the intermontane basins downstream.

Based on the lithology of gravels the writer divided the Mogami River into 6 parts, i. e. 
a) The Matsukawa River in the Yonezawa Intermontane Basin, b) The Shirakawa River and Main Mogami in the Nagai Intermontane Basin, c) The river course in the Arato Gorge and Yamagata Intermontane Basin, d) The river course in the Oyodo Gorge and Obanazawa Intermontane Basin, e) The river course in the Shinjo Intermontane Basin, and f) The Mogami Gorge and Shōnai Plain. From the view-point of river bed sedimentation, the mainstream of the Mogami River consists of the six different reaches which alternate erosion and deposition respectively.

The clear differences in lithology and diameter of the gravel of the six reaches show that the depositional function of the intermontane basin is very important. Due to the deposition in the Yamagata, Obanazawa and Shinjo Intermontane Basins, no gravel of more

Table 8 Changes of the largest gravels in rivers

(1) Ishikari River

\begin{tabular}{|c|c|c|c|c|c|c|c|}
\hline & TOPOGRAPHY & VALLEY & \multicolumn{2}{|c|}{ BASIN } & \multicolumn{2}{|c|}{ GORGE } & FAN \\
\hline \multirow{2}{*}{\multicolumn{2}{|c|}{ LOCATION }} & AIBETSU. & A SAHI Br & KAMEYO & CENTRAL & KAMUI & VESTIGE \\
\hline & & BANGAICHI & 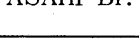 & SHI-CHO & CANYON & KOTAN & CAVE \\
\hline \multirow{4}{*}{ 䍃 } & SAND STONE & 50 & 27 & 19 & & 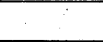 & 16 \\
\hline & IGNEOUS ROCK & . & 24 & 25 & & & 16 \\
\hline & CHERT & & 17 & 26 & & & 29 \\
\hline & CHLORITE, SCHIST & & & & 370 & 500 & 63 \\
\hline
\end{tabular}

(2) Kuzuryū River

\begin{tabular}{|c|c|c|c|c|c|c|c|c|}
\hline \multicolumn{2}{|r|}{ TOPOGRAPHY } & \multicolumn{4}{|c|}{ ONO BASIN } & \multicolumn{2}{|c|}{ NARROW } & \multirow{2}{*}{$\begin{array}{l}\text { FAN } \\
\text { GOMATSU } \\
\text { Br. }\end{array}$} \\
\hline & LOCATION & IMAI & TOMO KANE & $\begin{array}{l}\text { KIMIGA- } \\
\text { YO Br. }\end{array}$ & $\begin{array}{l}\text { JUNCTION } \\
\text { MANA R. }\end{array}$ & $\begin{array}{l}\text { KATSU } \\
\text { YAMA }\end{array}$ & $\begin{array}{l}\text { KOBUNE } \\
\text { WATASHI }\end{array}$ & \\
\hline \multirow{4}{*}{ 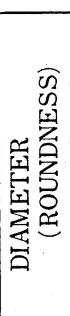 } & GRANITE & $\begin{array}{l}136 \\
(4)\end{array}$ & $\begin{array}{l}95 \\
(5) \\
\end{array}$ & $\begin{array}{l}49 \\
(6) \\
\end{array}$ & $\begin{array}{l}15 \\
(5) \\
\end{array}$ & $\begin{array}{l}68 \\
(5) \\
\end{array}$ & $\begin{array}{l}110 \\
(5) \\
\end{array}$ & $\begin{array}{r}50 \\
(5) \\
\end{array}$ \\
\hline & PORPHY RITE & & & & & $\begin{array}{l}75 \\
(5)\end{array}$ & $\begin{array}{r}55 \\
(5)\end{array}$ & $\begin{array}{l}25 \\
(5)\end{array}$ \\
\hline & CONGLOM ERATE & $\begin{array}{r}95 \\
\text { (4) }\end{array}$ & $\begin{array}{l}77 \\
(5)\end{array}$ & $\begin{array}{l}49 \\
\text { (5) } \\
\end{array}$ & $\begin{array}{l}21 \\
(5) \\
\end{array}$ & $\begin{array}{l}50 \\
(4) \\
\end{array}$ & $\begin{array}{r}13 \\
(6) \\
\end{array}$ & $\begin{array}{c}30 \\
(6) \\
\end{array}$ \\
\hline & SAND-STONE & & & & & $\begin{array}{l}85 \\
(5)\end{array}$ & $\begin{array}{l}120 \\
(5)\end{array}$ & $\begin{array}{l}50 \\
(5)\end{array}$ \\
\hline
\end{tabular}

(Oya \& Akagiri, 1968)

(3) Chikugo River

\begin{tabular}{|l|c|c|c|c|c|c|c|}
\hline \multirow{2}{*}{ TOPOGRAPHY } & \multirow{2}{*}{ PIEDMONT } & $\begin{array}{l}\text { HANDA- } \\
\text { PLATEAU }\end{array}$ & \multicolumn{2}{|c|}{ GORGE } & \multicolumn{3}{c|}{ KUSU BASIN } \\
\hline LOCATION & YUTSU-BO & BUNGO & JUTASHI & \multirow{2}{*}{ NOGAMI } & \multicolumn{2}{c|}{ IWAMURO } & UOGAESHI FALL \\
\cline { 3 - 8 } & WAGARI & UOPPR & LOWER \\
\hline DIAMETER & 350 & 71 & 249 & 400 & 175 & 85 & 215 \\
(ROUNDNESS) & $(5,4)$ & $(6,5)$ & $(5,4,3)$ & $(5,4)$ & $(5,4)$ & $(4,6)$ & $(5,4)$ \\
\hline TOPOGRAPHY & \multicolumn{3}{|c|}{ AMAGASE GORGE } & & HIDA BASHIN \\
\hline LOCATION & POWER PLANT & AMAGASE & ICHINOTSURI & KAWAHARA & KUMA & NAKANOSHIMA \\
\hline DIAMETER & 250 & 500 & 315 & 270 & 167 & 100 \\
(ROUNDNESS) & $(5,4)$ & $(5,4)$ & $(5,4)$ & $(5,6)$ & $(6)$ & $(6)$ \\
\hline
\end{tabular}

unit : $\mathrm{cm} \quad$ (roundness by Krumbein) 
Table 9 Width and length of the natural levee

(1) Natural levees which have no intermontane basins in the upper reaches "On " group

\begin{tabular}{|l|c|c|}
\hline \multicolumn{1}{|c|}{ Name of river } & Width $(\mathrm{km})$ & Length $(\mathrm{km})$ \\
\hline R. Iwaki & 3 & \\
R. Kiso (along R. Kuroda) & 2 & 22 \\
\hline
\end{tabular}

(2) Natural levees which have intermontane basins and gorges with knick points in the upper reaches "Od" group

\begin{tabular}{|l|c|c|}
\hline \multicolumn{1}{|c|}{ Name of river } & Width $(\mathrm{km})$ & Length $(\mathrm{km})$ \\
\hline R. Ishikari & 2.5 & \\
R. Mogami (Yamagata Intermontane & 2.5 & 19.5 \\
Basin) & 3 & 69 \\
R. Tone (along R. Furutone) & 1.5 & 16 \\
R. Yamato (along R. Nagase) & 1 & 5.5 \\
R. Kuzuryū & \\
\hline
\end{tabular}

than $64 \mathrm{~mm}$ in diameter flows down from the upper reaches to the Shonai Plain via the Yamagata, Obanazawa and Shinjo Intermontane Basins. Gravel is only provided in the Mogami Gorge. Because the absolute volume of the gravel which flows down to the Shōnai Plain is small, only a small fan has been formed.

The largest gravel in the river bed sediments shows the critical tractive force in each sampled stations of the rivers. The diameter of the largest gravel so far measured, is $26 \mathrm{~cm}$ in the Kamikawa Intermontane Basin in the Ishikari River, $21 \mathrm{~cm}$ in the Ono Intermontane Basin in the Kuzuryū River, $85 \mathrm{~cm}$ in the Kusu Intermontane Basin and $100 \mathrm{~cm}$ in the Hida Intermontane Basin in the Chikugo River. No larger gravel flowed down to the plain except the gravel which has been furnished in the gorges located between the intermontane basins and plain, i. e. the Kamuikotan Gorge in the Ishikari River, the Katsuyama Narrows in the Kuzuryu River and the Amagase and Yoake Gorges in the Chikugo River. The above mentioned phenomena have also been verified by the roundness of the gravel (Tables 8-1, 2, 3).

Based on the above mentioned change of diameter and roundness of the largest gravel, we see that a considerable part of the large gravel which is transported from the upper reaches is deposited in the intermontane basin, while only sand and small sized gravel are allowed to continue flowing down the river to the plain. Gravel found in the fan is mainly furnished by the gorge between the intermontane basin and plain. Therefore, the absolute volume of the gravel is small and only a small fan was constructed. The above mentioned alternation of erosion and deposition in gorges and basins has been still continuing. At the time of the flood in 1953, erosion occurred in the Amagase Gorge and the Yoake Gorge, but deposition occurred in the Hida and Kusu Intermontane Basin.

According to data on the crustal movement from 1893 to 1963 which has been calculated by the author utilizing the first order bench mark, the Kusu Intermontane Basin sunk 9.19 $\mathrm{cm}$, while the Amagase Gorge rose $9.2 \mathrm{~cm}$ (Oya, $1973 \mathrm{a}$ ). The same phenomenon is re- 


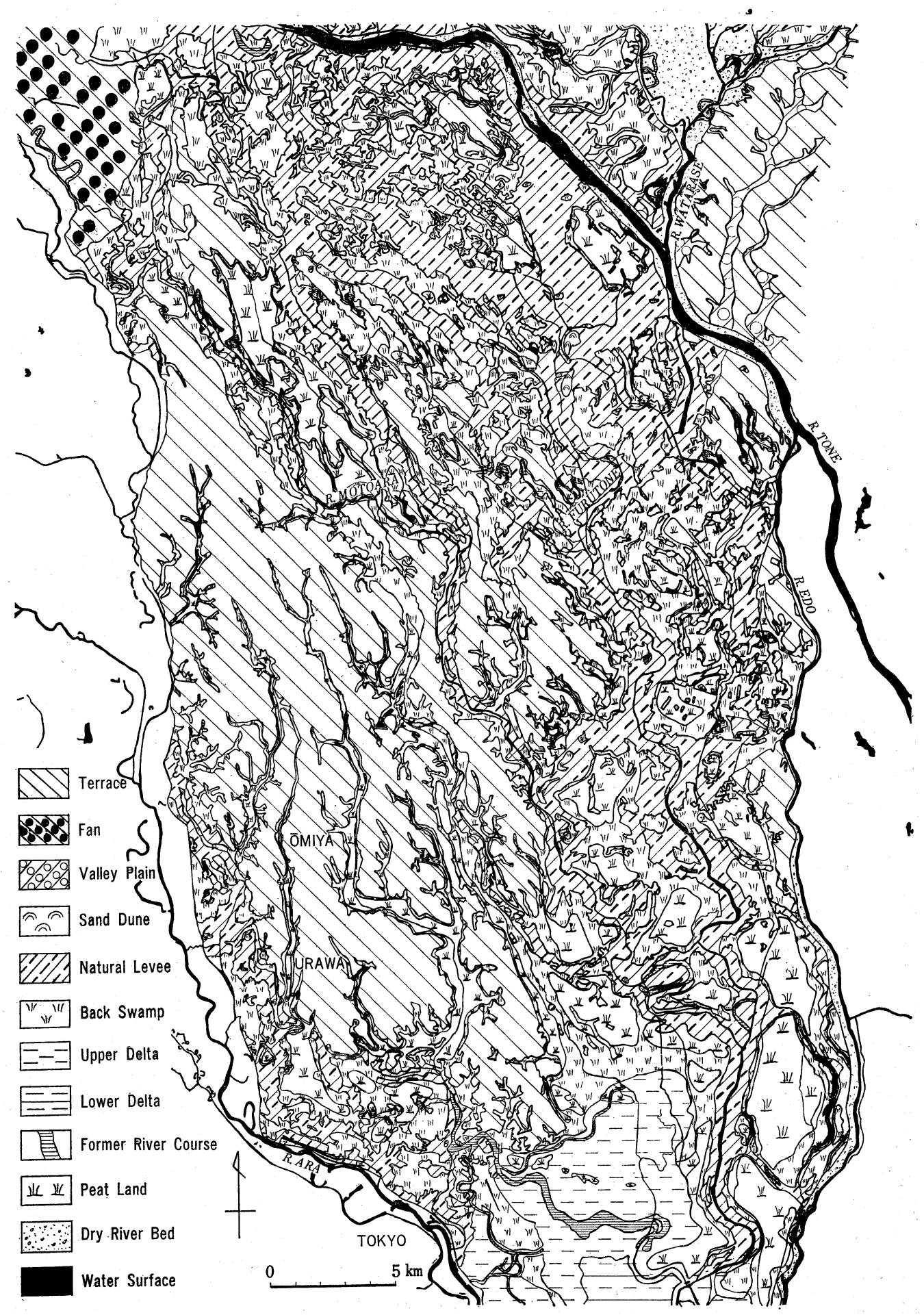

Fig. 8 Geomorphological land classification map of the middle reaches of the Tone River 


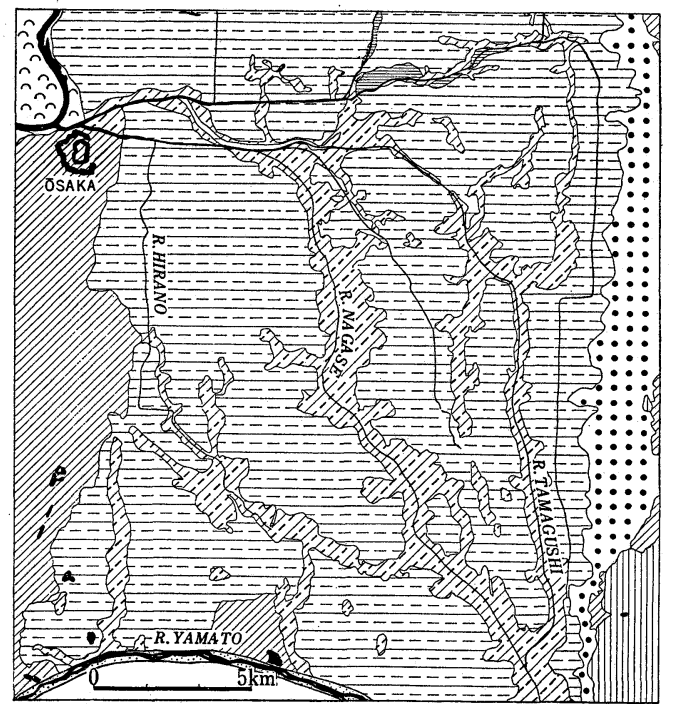

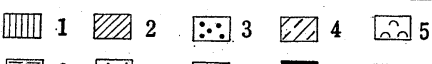

1. Mountain

2. Terrace

3. Fan

4. Natural Levee

5. Sand-spits

6. Delta

7. Dry River Bed

8. Former River Course

9. Water Surface

10. River and Dike

(Oya \& Nakamura, 1969)

Fig. 9 Geomorphological land classfication map of the lower reaches of the Yamato River ported in the basin of the Mogami River (Tada, et al. 1970). This crustal movement is one of the causes for stopping the flow of the sand and gravel to the lower reaches. The following condition in the upper and lower reaches will be added to the causes. Regarding the slopes of the mountain, those of the Ishikari and Chikugo Basin are gentler than those of the Kiso Basin. As might be expected the relief energy of the Ishikari and Chikugo River Basin is smaller than that of the Kiso (Table 6). As a result of the above mentioned geomorphology, few basic factors which might cause land collapse in the entire Ishikari and Chikugo River Basins exist.

There are many steep slopes in the Kuzuryū River Basins, but there are few places where the steep slopes abut directly on the rivers. Thus when landslides occur, the debris dose not reach the river bed directly but is deposited on the flood plain. (Oya \& Akagiri, 1968). The width of the flood plain where the fan has been developed is narrow, i. e. the maximum width is only $3 \mathrm{~km}$ in the Ishikari, $2.75 \mathrm{~km}$ in the Mogami, and $3.5 \mathrm{~km}$ in the Chikugo (Fig. 10).

The fan of the Tone River at the junction between the mountain and plain, near Shibukawa City, looks like a gravelly valley floor plain. The reasons for this are partly that the width of the flood plain near Shibukawa City is too narrow to allow the fan to develop and partly that some part of the sand and gravel have been deposited in the Numata Intermontane Basin in the upper reaches.

There is no fan along the mainstream of the Mogami in the Yamagata Intermontane Basin. This fact results from the following : a) there are the Yonezawa and Nagai Intermontane Basins in the upper reaches, b) the longitudinal profile of the river bed is gentle between the Arato Gorge and Yamagata Intermontane Basin and c) the Arato Gorge con- 


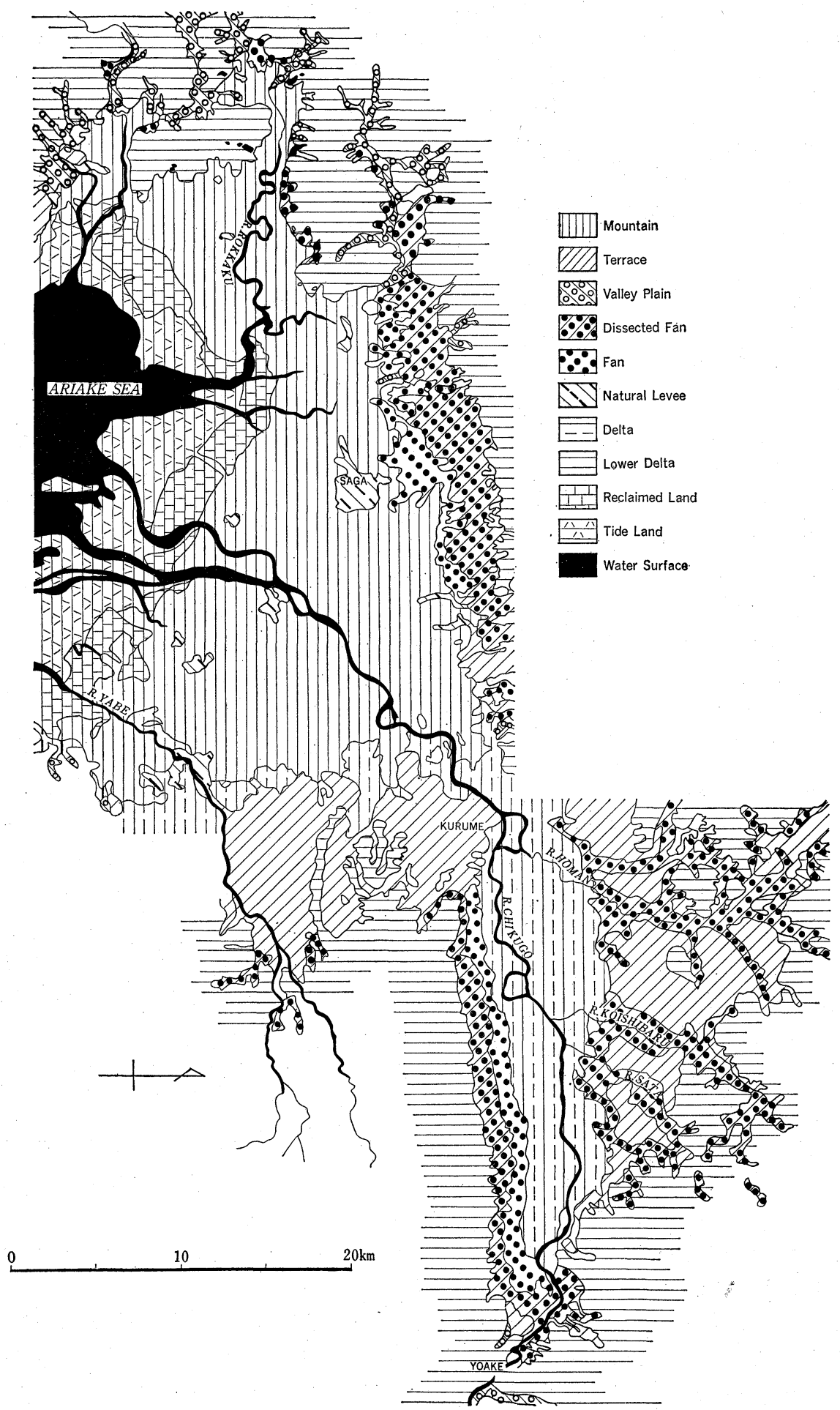

Fig. 10 Geomorphological land classification map of the Chikugo Plain (Oya, 1973 a) 
sists of tuff which will be easily decomposed into sand.

In the case of the Osaka Plain there is no fan along either the Yodo River or the Yamato River, because of the existence of Lake Biwa, Kameoka Intermontane Basin, Kyoto Intermontane Basin, Ogura Pond in the Yodo River and Nara Intermontane Basin, etc. in the Yamato River.

(2) Features of the natural levee

In spite of the small size of the fan, the natural levee is developed well, as shown in Table 9-2. In these plains, the nearer to the river the land is, the higher it becomes. In the case of the Ishikari Plain and Yamagata Intermontane Basin, we see only one stripe of natural levee along the mainstream. On the other hand bifurcation of the natural levees is seen in the middle reaches of the Tone River and lower reaches of the Yamato River (Figs. 8, 9). There are few natural levees in the Shōnai and Chikugo Plain (Fig. 10). In these plains, the closer to the river the land is, the lower it becomes.

When a river has intermontane basins (the Ishikari River, Tone River, Yamato River, etc.), the heavier gravel which is transported from the upper reaches is deposited in the basins while a lot of sand and small gravel is allowed to continue on its way and form large natural levees in the plain.

Both tuff, which is distributed along the Arato Gorge of the Mogami River, and granite, which is distributed in the tributaries that are joined to the mainstreams in the gorge, are easily broken down into sand. The Mogami River developed the natural levee composed of sand in the Yamagata Intermontane Basin.

Drainage basins of the upper reaches of the Tone River are volcanic region. Therefore, a lot of fine materials, i. e. pumice, volcanic ash, etc. have been furnished in the upper reaches and have passed through the Numata Intermontane Basin without deposition and have flowed down to the plain. Then big natural levees have been formed. The many pumice fragments in the natural levees deposits are proof of it. Big natural levees in the Osaka Plain were formed by the sand derived from deepy weathered granite rocks in the upper reaches of the Yamato River.

There is a natural levee long the mainstream of the Ishikari River and the Mogami River in the Yamagata Intermontane Basin. In the case of the Ishikari River, the shifting of the river course has been slight partly because the flooding caused by melting of snow is moderate and partly because even though the flooding caused by typhoon is severe, the back marshes along the river course are covered by vegetation in summer (Sakaguchi, 1974). This vegetation prevents a change of the river course despite the great volume of typhoon floods. And in the Yamagata Intermontane Basin shifting of the river course did not occur, because the area of the flooding from the mainstream is so narrowly limited by the fans of tributaries in the basin.

On the other hand, in the middle reaches of the Tone River, there are several stripes of the natural levees along the Furu-Tone River and the Ainokawa River, etc., also in the lower reaches of the Yamato River, along the Nagase River, the Tamaguchi River and Hirano River (Fig. 8,9). The author presumed that the reasons for this are as follows : the gra- 

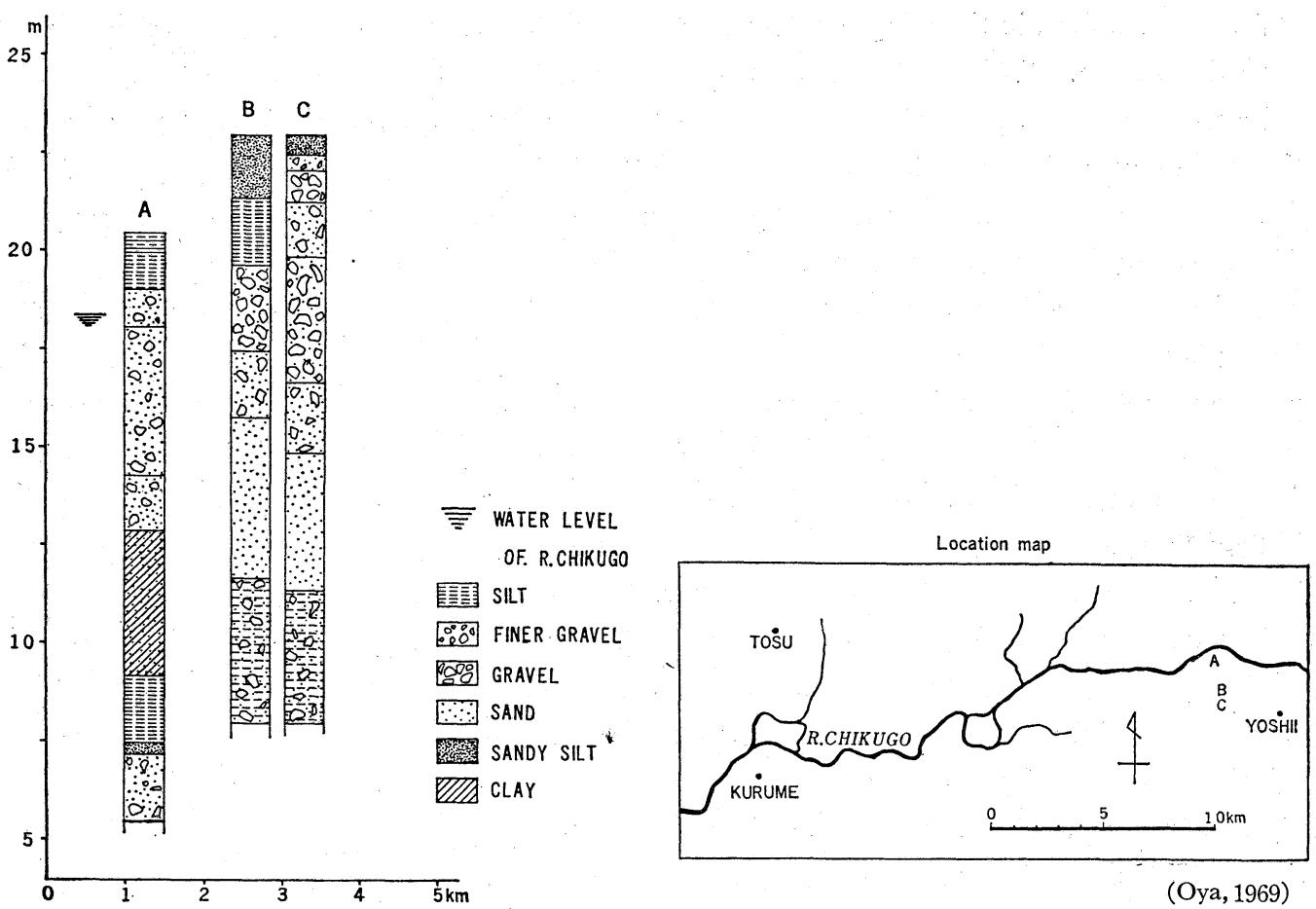

Fig. 11 Geological cross-section of the Plain in the middle reaches of Chikugo River

dient of the middle reaches of the Tone River and lower reaches of the Yamato River have become steeper because of the crustal subsidence which is stronger (Oya \& Nakamura, 1969) than that of the Ishikari Plain, and the flood hydrograph discharge of the Tone and Yamato River are steeper than that of the Ishikari Plain.

There are few natural levees in the Chikugo and Shōnai Plain. In the case of the middle reaches of the Chikugo River, there are large fans formed by the tributaries down the mountains both from the north and south into the main course. Due to the fans, the width of the flooded area along the main course of the Chikugo River is not great, a maximum of 7.2 $\mathrm{km}$ (Fig. 10). On account of the topography, the flood water flows down from the higher surrounding area into the mainstream. In fact, even when overflow from the mainstream occurs, the flood waters do not disperse but flow in a narrow concentrated stream near the mainstream, finally flowing into the mainstream again at the lower reaches. This type of flooding contrasts with the overflow type represented by the Kiso River. On account of the erosion along the mainstream, the closer to the river the land is, the lower it becomes. Columnar sections show that the sandy silt layer which is deposited on the top of the area is absent near the river course (Fig. 11). This indicates recent erosion along the mainstream. Furthermore, because of several short cuts and the building of continuous embankments, the velocity of the flood current, excavation of river bed sediment, and cutting off the sand supply by the construction of Yoake Dam, the river bed has been lowered remarkably (Oya, 1973). 
As stated before, in the middle reaches of the Chikugo River, erosion is more predominant than deposition. This is the reason why there are few natural levees.

In the case of the Shōnai Plain, the volume of sand and gravel which is transported by the main stream is small due to the deposition in the intermontane basins (Oya, 1974 b). On the other hand, the volume of the sand and gravel which have been transported by the Aka River in the southern part and Nikko and Gakko in the northern part of the plain are considerably large in spite of the small size of the river, because they have no intermontane basins in their upper reaches. As a result of the remarkable deposition by these tributaries and small deposition by the mainstream, when floods occur the flood waters do not disperse but flow in a narrow concentrated stream near the main stream, about 2 to $6 \mathrm{~km}$ in width. Therefore, a natural levee has not developed along the mainstream of the Mogami River in Shōnai Plain.

(3) Features of the delta and its regional differences

Except for the Yamagata Intermontane Basin, every plain has a delta. The delta occupied about $64.5 \%$ of the Kuzuryū Plain and $86.3 \%$ of the Osaka Plain. These deltas were formed initially as subaquatic deltas and then became subaerical deltas due to the relative lowering of sea level, and some parts of them have been reclaimed. The surfaces of the deltas are very flat because the fluvial deposits are few. But in the case of the Chikugo and Shōnai delta, the nearer to the river the land is, the lower it becomes.

The greater part of the plain along the lower reaches of the Tone River was subaquatic delta which was formed in the Katori Sea. Except for around the lower reaches of the Kokai River, there are few natural levees along the river course in the lower reaches and the ground level is horizontal. The author inferred the facts as follows. Before 1594, the Tone River flowed into Tokyo Bay. According to the construction records from 1594 to 1809, the Tone River was joined to the lower reaches of the Kinu River causing its course into the Pacific Ocean. The volume of the sand, silt and clay from the Kinu and Kokai River is lesser than that of the Tone and Watarase Rivers, because the area, relief energy, and flood discharge of the former is smaller than that of the latter. Furthermore, the volume of the sand and gravel which has been transported by the Tone River is small partly because only a few hundred years have passed since the connection between the Tone and Kinu, partly because the greater part of the sand and gravel has been deposited in the middle reaches due to subsidence of the ground and partly because parts of fine materials have poured into Tokyo Bay via the Edo River (Oya, 1971 a).

The delta which is located between the Yodo River and Neya River in the Osaka Plain was a subaquatic delta which was formed during the transgression period and which became a subaerial delta mainly due to the relative lowering of the sea level, but also because the fluvial deposit is small. The features have been formed by the greater part of the sand and gravel which was transported by the Yodo River being deposited at the upper part of the Yamazaki Narrows because there are many intermontane basins. Also deposition of the Yamato River has been stopped at the line of Neya for the Yamato River was shifted artificially in 1704 (Oya \& Nakamura, 1969). The delta which is located in the western 

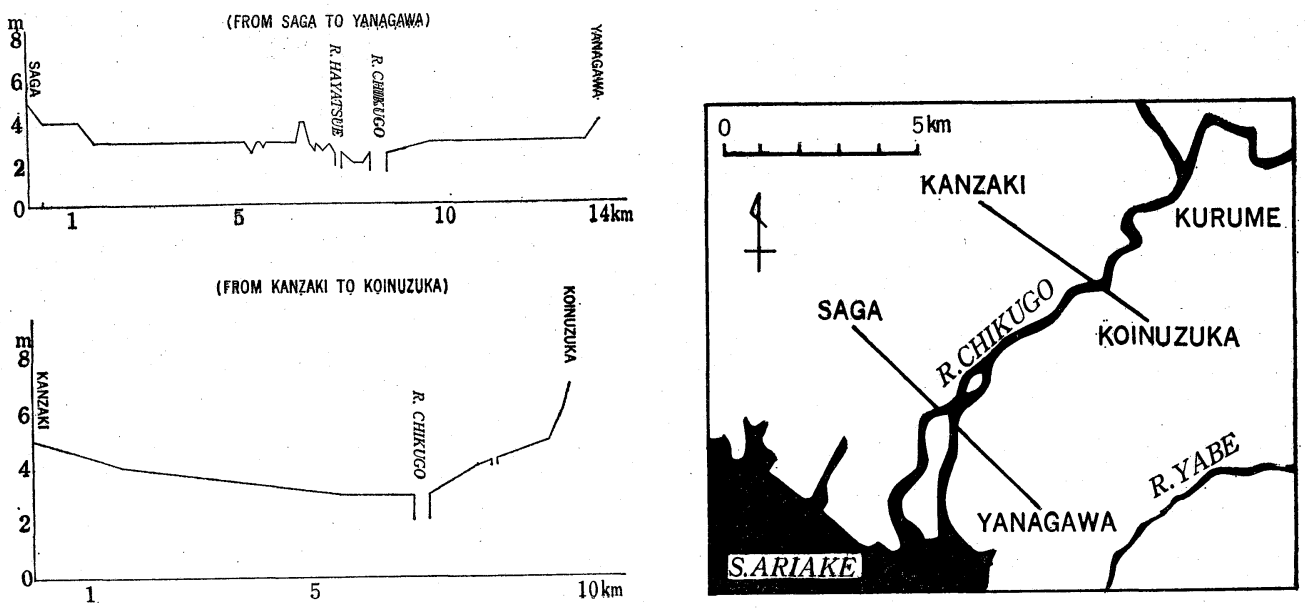

(Oya, 1973 a)

Fig. 12 Torographical cross-section of the plain of the lower reaches of the Chikugo River

part of the Tenma Terrace and Tenma Sand Spits has been reclaimed since 1936.

At the time of regression in the Holocene, the subaquatic delta which was developed from the Kurume Narrow of the Chikugo River to the south-west became a subaerial delta as a result of the lowering of the sea level and fluvial deposition. The Kurume Narrow is made of bed rock consisting of crystalline schist. Rock which formed the narrow was excavated by Yoshimasa Tanaka in 1901. Before the excavation, the Chikugo River bulged out to north of the present river course and was somewhat narrower than at present (Oya, $1973 \mathrm{a}$ ). The ground has sunk about 40 to $90 \mathrm{~cm}$ between 1890 and 1964 in the central part of the middle reaches.

Because of the existence of the narrows, subsidence of the middle reaches, and the geomorphological features of the upper reaches, the amount of sand and gravel which is transported from the upper and middle reaches by the Chikugo River is small. Therefore, the depth of the fluvial deposits is very shallow in the delta.

The tidal difference at the river mouth is great, the maximum in a year being about $6 \mathrm{~m}$, and the influence is felt as far inland as the city of Kurume. In fact, the tidal difference is so great that the direction of river flow reverses each day, and the velocity of river current becomes fast, (about $1 \mathrm{~m} / \mathrm{sec}$ according to the observation of Chikugo River Construction Office), enough to cause erosion of the river bed and bank.

Furthermore, lowering of the river bed has been taking place in recent years partly because of the increase of flood current due to the completion of the short cuts, and partly because of extraction of sand and gravel from the river bed for use in construction project. Because of the above mentioned natural features and human works, erosion has been going on in the lower reaches for a long time.

Just as in the middle reaches, the nearer to the river the land is, the lower it becomes (Fig. 12). The mainstream flows down along the lowest part of the delta forming a deep channel with a maximum depth of $5.3 \mathrm{~m}$ below sea level. 


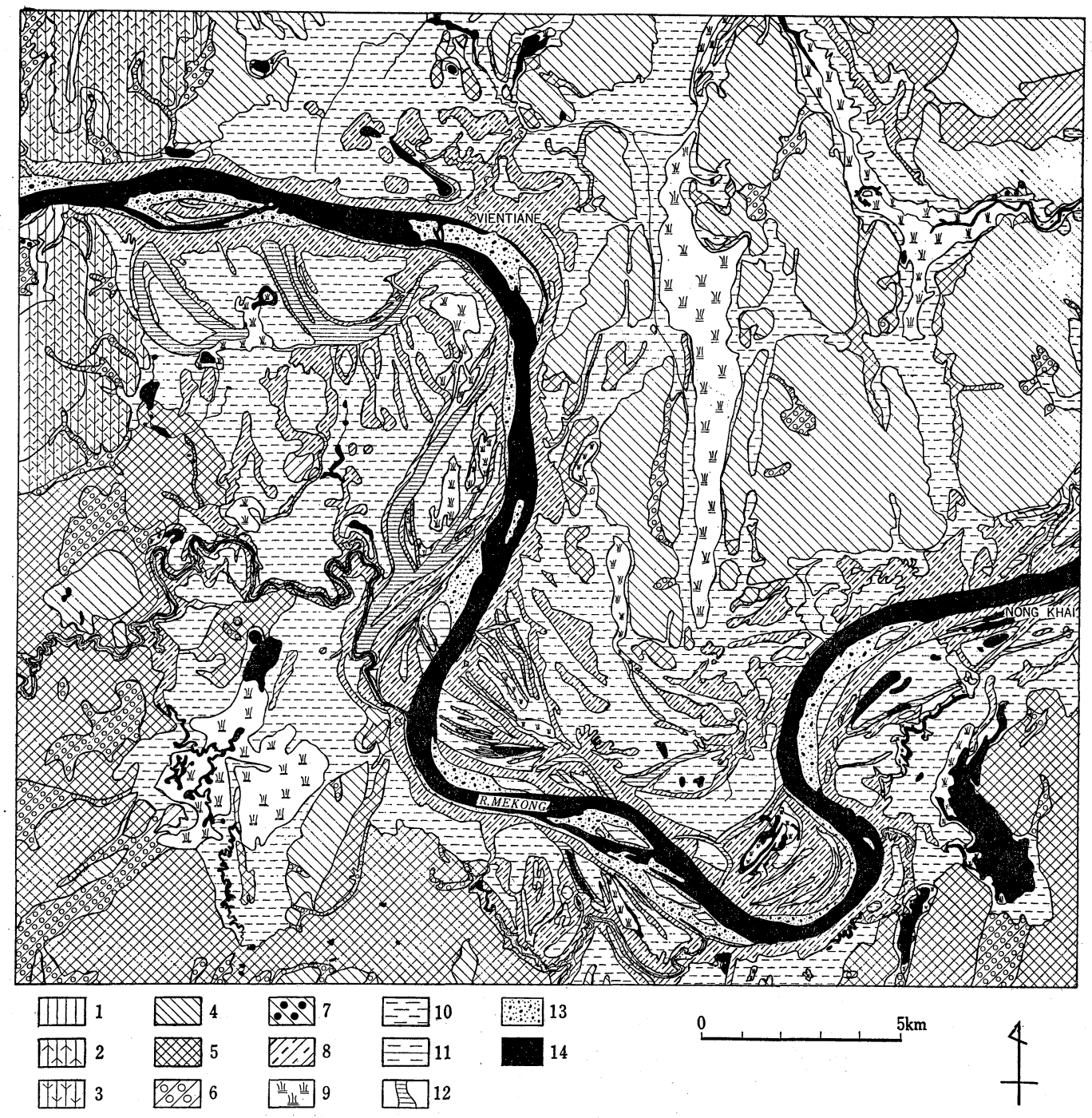

Fig. 13 Geomorphological land clssification map of the Vientiane Plain

1. Mountain Slope 2. Gentler Mountain Slope 3. Piedmont Gentle Slope 4. Terrace

5. Lower Terrace 6. Valley 7. Fan 8. Natural Levee 9. Marsh 10. Delta 11. Lower

Delta 12. Former River Course 13. Dry River Bed 14. Water Surface

In the case of the Shōnai Plain too, the amount of deposition by tributaries is more than that of the mainstream, the flood water does not disperse but flows in a narrow concentrated stream down near the mainstream. Therefore, the delta has been eroded along the mainstream.

In the orogenic zone, there are many intermontane basins along the river courses. In Japan too, many rivers have many intermontane basins. When a river has a intermontane basin, a considerable part of the heavier gravel which is transported from the upper reaches 

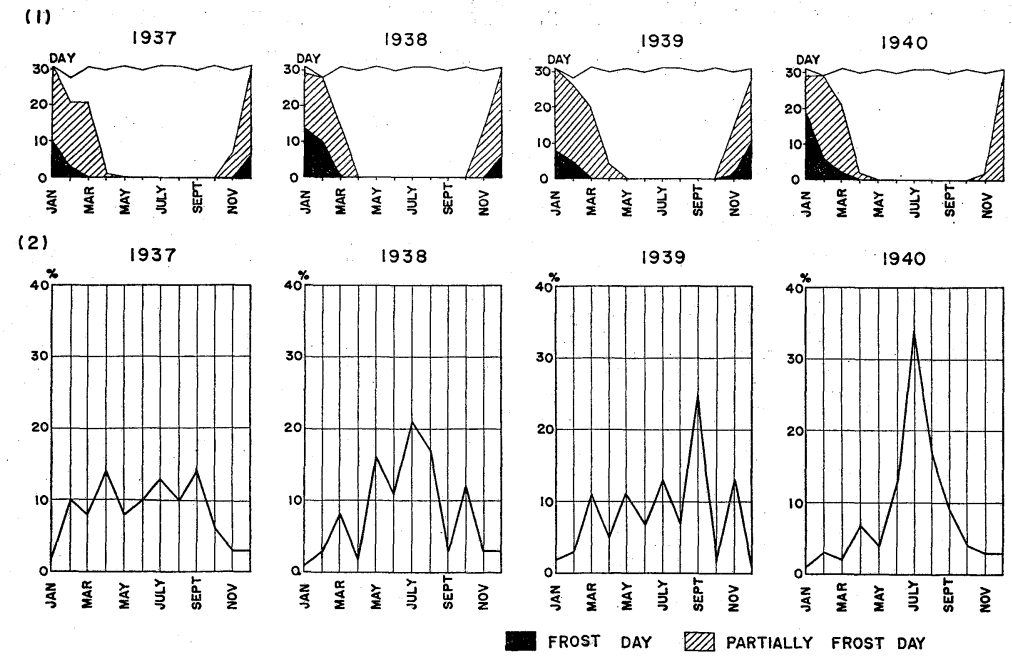

Fig. 14 Number of "Frost days" and "Partially Frost days" and ratio of monthly rainfall to the annual at Chupungnyang

is deposited in the basin, while only sand and small gravel is allowed to continue on its way together with debris which has been furnished in the gorges located between the basin and plain. Therefore, only a small-size fan has been formed or none at all. The materials of the small fan are slightly related to the geomorphology and geology of the upper reaches but closely related to that of the gorge between intermontane basins and plains.

And the features of the natural levees are influenced remarkably by the features of the basin of deposition, i. e. the width of the basin, the relationships between the deposition of the mainstream and tributaries, the crustal movement and the nature of the flooding. On account of the features in the basin of the deposition, in some areas, there is a natural levee along the mainstream, but in another areas, bifurcation of the natural levee is seen.

The greater part of the delta has been altered from a subaquatic delta to a subaerial delta due to the relative lowering of the sea level and a small fluvial deposition. As a result of the formation process, almost the entire surface of the delta is flat. But in some deltas because of the erosion along the mainstream, the nearer to the river the land is, the lower it becomes.

The regional differences of the geomorphology of the delta result from the features of the basins of deposition rather than from the materials which have been transported from the upper reaches.

\section{"'E' group}

The most important feature of the plain is that there are few alluvial fans, in spite of severe mechanical disintegration in the mountains. This is partly because the mountain is in an old stage of development with no deep valleys, and partly because the amount of sand and gravel reaching the plain is small, since the slope of the piedmont is gentle.

In spite of the location of the Vientiane Plain being in the lower reaches of the Pa Mong Gorge, there are few fans at the junction of the gorge and plain (Fig. 13) (Oya, 1967). And 
there is no fan in the Mekong Plain either. There develops topography that looks like a fan but it is very small and flat, and includes small gravel of about $1 \mathrm{~cm}$ diameter here and there in the Chao Phraya Plain.

The reasons for the lack of development of the fan in both the Mekong and Chao Phraya Plain are as follows : a) there is little land collapse as the slope of the mountain is gentle, because of the basins being located in the epeirogenic zone and therefore in the late stage of the cycle of erosion, b) the slope of the river is gentle.

The second featue of the plains is that there are remarkable natural levees. In the Naktong River, the width of the flood plain is narrow, only $1 \mathrm{~km}$, but the natural levee is well developed, its width is $0.7 \mathrm{~km}$ and its relative height is $7 \mathrm{~m}$. the height being increased by the repetition of flooding. According to the observation near Koryon Bridge along the mainstream, the natural levee was heightened about $1.5 \mathrm{~m}$ by just one flood in 1968 . The reason why natural levees have been developed is as follows: Fig. 14 shows that frost and partially frost days occur during the winter and precipitation is concentrated during the summer. Annual and dianural variation of temperature is marked in this region. The debris which has been formed during the winter by the mechanical disintegration will be washed away by the torrential rainfall during the summer (Oya, $1971 \mathrm{~b}$ ).

But the debris which has reached the river bed is small because the slope of the piedmont is gentle. Furthermore, the gravel is not transported by the river flow as the gradient of the river is gentle. But a lot of sand was transported long distance by the river flow and has formed big natural levees. The reasons for the volume of the sand which has been deposited in the Naktong River being great, especially in the region of the Shobek Mountain, are the mountains consists of granite and the vegetation cover is poor.

There is a knick point which has been formed by the difference in the hardness of the rock at the Hyopchun Damsite in the Hwan River, one of the tributaries of the Naktong. There are distinct regional differences in the river bed sediments between the area upstream from the knick point and that of downstream. There are both sand and gravel in the former, but only sand in the latter. This shows that almost all of the gravel has not been transported from the upper reaches to the lower reaches through the knick point. But small sized sand can flow through the gorge to the lower reaches. The volume of the sand is great, the natural levee along the Hwan River being heightened by about $2 \mathrm{~m}$ by just one flood in 1969 (Oya, 1971 b).

There are distinct natural levees with a width of $1 \mathrm{~km}$ and a relative height of $4 \mathrm{~m}$ along the mainstream of the Mekong in the Vientiane Plain (Fig. 13).

There are four distinct natural levees in the Chao Phraya Plain. The reason for the development of such big natural levees is that a lot of fine materials such as red soil have been deposited in the rainy season.

There are intermontane basins called Chieng Mai, Lam Pang etc. in the upper reaches. But a lot of fine materials, i. e. sand, silt and clay, can flow down through the intermontane basins to the lower reaches because deposition in the intermontane basins is limited, and because the topography in the basins shows an old stage of development. 
The river courses of the Mekong and Chao Phraya are more stable than the Brahmaputra-Jamuna River. This is one cause of the development of the natural levees in the Mekong and Chao Phraya Plain. On the other hand, in the case of the BrahmaputraJamuna Plain in the orogenic zone the natural levee has been developed fragmentarily due to the flooding of the area.

In the epeirogenic zone, there are few fans because the amount of gravel transported by the river is small. Furthermore, in the tropical region, the formation of fans is difficult, for the rock is generally weathered not to gravel but to red soil. But natural levees are very big partly because fine materials can flow through the intermontane basins due to the topography which shows them in an old stage of development, partly because a lot of fine material is furnished in flood time, and partly because the river course is more stable than that in the orogenic zone.

\section{Conclusion}

Based on the geomorphological land classification, the author has conducted an inductive comparative study of the fluvial plain. Firstly, he has studied fluvial plains in Japan that are small but whose geomorphological features are well known through many studies and systemically conducted research. Secondly, utilizing the same method, he studied 8 large fluvial plains in East and South East Asia which have received few geomorphological studies.

The author has classified the plains into two groups by their geomorphological location: plains in the orogenic zone and in the epeirogenic zone. Next, he classified the plain into plains which have intermontane basins and gorges with knick points and those that do not. The results of the study are shown in the Tables 3, 4 and 5 .

Comparing these tables, the following items become evident :

1. fluvial plains which have no intermontane basin in the upper reaches in the orogenic zone ; “On" group for example the Tsugaru Plain, Tsurumi Plain, Nobi Plain, Cho Shui Chi Plain and Brahmaputra-Jamuna Plain.

(1) In the orogenic zone, the cycle of deposition is young because a lot of sand and gravel derived from the mountain region in which the cycle of erosion is young flows down to the plain without stopping on its way for the lack of intermontane basins. And the arrangement of the geomophological elements-fans, natural levees and back marshes, and deltas is seen clearly from the upper to the lower reaches in the fluvial plains of this group.

(2) The geomorphological elements in the plain such as the size, slope and geology (particulary whether or not there is gravel), together with the nature of the fan and the length and continuity of the natural levee, are reflected to a remarkable degree in the physical condition of the upper reaches.

2. fluvial plains which have intermontane basins and gorges with knick points; "Od" group for example the Ishikari Plain, Yamagata Intermontane Basin, Shōnai Plain, middle and lower reaches of the Tone River Plain, Fukui Plain, Osaka Plain and 


\section{Chikugo Plain.}

(1) There are small fans as in the Ishikari Plain, Shōnai Plain, Fukui Plain and Chikugo Plain or none as in the Yamagata Intermontane Basin along the mainstream of the Mogami, middle and lower reaches of the Tone River Plain and the Osaka Plain.

When a river has intermontane basins, a considerable part of the heavier gravel which is transported from the upper reaches is deposited in the basin while only sand and small size gravel is allowed to continue on its way and reach the plain. Therefore, a considerable part of the coarse materials in the fan is obtained at the gorge and only a small part of those was transported from upper reaches. Then the size of the fan becomes small because the absolute volume of the coarse materials which has been transported by the river is small.

Therefore, the materials of the fan are related closely not to the geomorphology and geology of the upper reaches but to that of the gorge between intermontane basins and plains.

(2). In spite of the small size of the fan, the natural levee is well developed especially in the Ishikari Plain, the Yamagata Intermontane Basin, the middle and lower reaches of the Tone River Plain and the Osaka Plain. The levee is well developed due to the fact that materials flow down to the plain without being deposited in the basins. Therefore, the features of the natural levee are related more closely to the geomorphology and geology of the upper reaches than to those of the fan.

(3) There are regional differences on the natural levees in these plains. There is a natural levee along the mainstream in the Ishikari Plain and Yamagata Intermontane Basin, but there are several stripes of natural levees in the middle reaches of the Tone Plain and Osaka Plain. And there are few natural levees in the Chikugo and Shonai Plain. The above mentioned regional differences in the natural levee result from the features of the basin of the deposition, i. e. crustal movement, features of the flooding, and relationship between the deposition of main stream and tributary.

(4) The surface of the delta is flat, because the delta was formed initially as a subaquatic delta and became a subaerial delta due to the relative lowering of the sea level. Fluvial deposition on the delta is limited. But in the case of the Chikugo and Shonai Delta, the nearer to the river the land is, the lower it becomes. The topography has been formed by erosion along the main stream caused by concentration of flooding near the main stream or by big tidal differences.

3. Fluvial plains in the epeirogenic zone "E" group in the case of the Naktong River Plain, Vientiane Plain in the middle reaches of the Mekong River and Chao Phraya Plain.

(1) There are few fans in the plain. The reasons for this are a) the volume of the gravel which flows down from the mountains to the river bed is small because the mountains have reached the old stage, b) in the case of the Mekong and Chao Phraya Basin, a lot of fine materials are produced but not much gravel.

(2) The topography along the course of the rivers has reached so old in stage that distinct natural levees are developed in every. plain partly because the fine materials have 
been produced in the basin, partly because the fine materials flow down to the plain without being deposited in the intermontane basins.

Therefore, the regional differences in the geomorphology of the natural levee are the reflection of the geomorphology of the upper reaches except that the features of the basin of the deposition are important regardless of the existence of the intermontane basin.

Acknowledgements

The author is grateful to Prof. Dr. Takamasa Nakano, Prof. Dr. Taiji Yazawa and Prof. Dr. Saburo Noma for their critical reviews of this mansuscript and for many helpful suggestions for its improvement. He wishes to express his heartfelt thanks to Prof. Dr. Fumio Tada who has focussed my attention on the geomorphological land classification of the fluvial plain, and has always encouraged him by giving valuable advices. Further He wishes express my thanks to Prof. A. W. Peterson and Prof. Ph. D. C. G. Cleaver who have kindly revised the English. 


\section{References Cited}

Morgan, J. P. and McIntire, W. C. (1959): Quaternary Geology of the Bengal Basin, East Pakistan and India. Bull. Geolo. Soc. of Amer. 70, 319 342.

Nakano, T. and Oya, M. (1960): Relationships between Geomorphology and flooding caused by Ise Wan Typhoon. Measurement (Sokury) June, 1960. 1 13.

Oya, M. (1964 a): Comparative study on the geomorphology and flooding in the plains of the Cho-Shui-Chi, Chao-Phraya, Irrawaddy and Ganges. Proceeding of the Symposium on the Scientific Problems of the Humid Tropicai zonc Deltas and their implications UNESCO, 23 28.

Oya, M. (1964 b): A Comparative Study on Geomorhhology and Flooding among the Plains of the Cho Shui Chi, Chao Phraya, Irrawaddy and Ganges. Geogr. Rev. Japan, 37, 1 20.

Oya, M. (1967): Geographical Study of Flood Immediately Down-stream from Pa Mong in the Mekong River. Report to ECAFF. $1 \sim 40$.

Oya, M. (1971 a): A Comparative Study on Geomorphology and Development in the Plains of the Middle Reaches and Lower Reaches of the Tone River. "Tone River" Union of Nine learned Societies, 32 42.

Oya, M. (1971 b): Geomorphological Flood Analysis on the Naktong River Basin, Southern Korea. Report to FAO. $1 \sim 77$.

Oya, M. (1971 c): Classification of alluvial plain based on the morphological characteristics. The Scientific Researches, The School of Education, Waseda University, 53 64.

Oya, M. (1972): Contribution of the Physical Geography on the Flood Control. Essays of Geographical Sciences, University of Hiroshima, $210 \sim 218$.

Oya, M. (1973 a): Relationship between Geomorphology of Alluvial Plain and Inundation. Asian Profile, 1, 3 $479 \sim 538$.

Oya, M. (1973 b): Basic-form of the combination of the Geomorphologic elements in the alluvial plain. The Scientific Researches, The School of Education Waseda University, 23 43.

Oya, M. (1974 a): Geomorphological Land Classification of the Alluvial Plain of Brahmaputra River. Preceeding of the Japan Geographical, 7, 111 112.

Oya, M. (1974 b): Fluvial Function of Intermontane Basins and Gorges in the Mogami River, Northeast Japan. Ann. Tohoku Geogr. Assoc., 26, 123 129.

Oya, M. and Akagiri, T. (1968): Relationship between the Geomorphology and Flooding in the Basin of the Kuzuryu in the Central Part of Japan. Geographical Sciences, 9, 1 13.

Oya, M. and Nakamura, S. (1969): Geographical Study on the Inundation Caused by the Local Rainfall in the Neyagawa River near Osaka. Miscellaneous Report of the Researcy Institute for Natural Resources, 72, $13 \sim 32$. Resources Council (1956): Reconnaissance Topographical Survey on Areas Subject to Flood, Part I, $79 \sim 80$.

Sakaguchi, Y. (1974): Geology of Peat Land. University of Tokyo Press, $329 \mathrm{p}$.

Tada, F., Oya, M., Ichinose, Y., and Mitsui, K., (1970): Report on the Forestry Conservancy and Flood Control of the Mogami River. Resources Bureau Science and Technics Agency, 211 p.

Umitsu, M. (1974): Buried Forest on the River Bed of the Iwaki in the Northeastern Part of Japan. Ouat. Research (Japan), 13, $217 \sim 218$.

(Received June 30, 1976 ; Accepted Nov. 19, 1976) 


\section{地形分類を基礎とした河成平野の比較研究}

\section{大 矢 雅 彦*}

（目的・方法）河成平野の地域性を地形要素の組み合わせと，それを形成した河川営力との関係を基礎に研 究した．この場合，河川の流路における盆地の有無による地域差に重点を置いた，扱った平野は日本 13 ，アジ ア 5 で，筆者が過去 20 年間にこれ等の平野で作成した地形分類図を用いて比較した．また，主要河川で河床 磞の粒度分析を行なった。

（成果）これ等の河成平野は，1．造山帯で流路に盆地のない平野 “On” 群（津軽，鶴見，濃尾，濁水渓， ブラマプトラ・ジャムナ平野)，2. 造山帯で流路に盆地，盆地と平野に挾まれる峡谷，遷急点のある河成平野 “Od”群（石狩，庄内，利根川中流部，沼津，福井，大阪，筑後平野ならびに山形盆地）および 3. 造陸帯の 河成平野 “E” 群（洛東江，ヴェンチャン，メコン，チャオプラヤ平野）の三群に分かれた. 各群平野の地形 要素とその組み合わせに基づく地域性は次のとおりである。

1. “On”群平野 1）扇状地，自然堤防，後背湿地およびデルタの組み合わせからなっている，2）堆積 のステージが新しい，自然堤防は全平野に発達し，洪水は本川より周辺部後背湿地またはデルタへ滑流する.

3）地形要素の形態，性質および組み合わせの相違は，堆積盆の条件を除けば，上流山地の地形，地質，降水 等の自然条件をそのまま反映している.

2. “Od”群平野 1) 扇状地は欠如するか，あっても小型である.これは，(1) 上流山地で供給された砂 礫のうち大粒径のものは盆地で堆積し，平野には小粒径のものだけが到達する. (2) 扇状地構成物質は盆地と 平野の間にある峡谷で供給された礫の比率が大で, 礫の絶対量は少ない，扇状地の規模，構成物質は上流山地 の地形，地質との関係はほとんどなく，むしろ，盆地と平野の間の峡谷の地形，地質と関係がある．2）自然 堤防は扇状地と異なり，石狩，利根川中流部，大阪平野および山形盆地ではよく発達している。これは自然堤 防を構成する細粒物質は盆地で堆積することなく平野まで流下するためである．3）自然堤防は本川に沿って 一条のみ発達する場合と幾条も発達する場合がある. この地域差は地盤運動, 洪水, 本支川の堆積力の大・小 等堆積盆の条件の地域差によって惹起されている．4）筑後，庄内平野には自然堤防はほとんどなく，地盤高 は本川へ近づくに従って低くなっており，平野は侵蝕過程にあると解釈される．洪水は周辺部高地から本川へ 流入するか，本川より渙流しても広範囲には拡撤せず，下流で再び本川へ流入する.5）デルタの大部分は海 面の相対的低下により水中デルタが陸化したもので，陸成堆積物少なくきわめて平坦である. 庄内，筑後デル タでは著しい潮差および本川への集中型洪水のため, デルタの一部は侵蝕過程にある.

3. “E”群平野 1) 扇状地はほとんどない。これは山地が老年期の地形で河床にまで達する礫が少ない こと，メコン，チャオプラヤ両川流域では細粒物質は生産されても，碟は生産されにくいためと解釈される.

2）自然堤防はよく発達する.これは流域で細粒物質の生産が大であること，盆地と平野との間に峡谷があっ ても，盆地，峡谷共に老年期に近い地形を呈し，盆地での堆積，峡谷での侵蝕はほとんどなく，上流山地から 供給された細粒物質は盆地，峡谷を通過し，平野にまで達するからである. 